\title{
Missing OH source in a suburban environment near Beijing: observed and modelled $\mathrm{OH}$ and $\mathrm{HO}_{2}$ concentrations in summer 2006
}

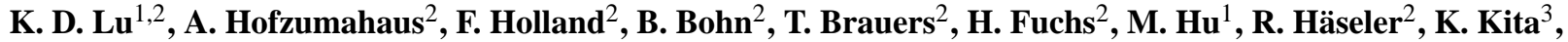 \\ Y. Kondo ${ }^{4}$, X. Li ${ }^{1,2}$, S. R. Lou ${ }^{2,5, *}$, A. Oebel, ${ }^{2, *}$, M. Shao ${ }^{1}$, L. M. Zeng ${ }^{1}$, A. Wahner ${ }^{2}$, T. Zhu ${ }^{1}$, Y. H. Zhang ${ }^{1}$, and \\ F. Rohrer ${ }^{2}$ \\ ${ }^{1}$ State Key Joint Laboratory of Environmental Simulation and Pollution Control, College of Environmental \\ Sciences and Engineering, Peking University, Beijing, China \\ ${ }^{2}$ Institut für Energie und Klimaforschung: Troposphäre, Forschungszentrum Jülich, Jülich, Germany \\ ${ }^{3}$ Faculty of Science, Ibaraki University, Ibaraki, Japan \\ ${ }^{4}$ University of Tokyo, Research Center for Advanced Science and Technology, Tokyo, Japan \\ ${ }^{5}$ School of Environmental Science and Technology, Shanghai Jiao Tong University, Shanghai, China \\ *now at: Shanghai Academy Of Environmental Sciences, Shanghai, China \\ ** now at: Carl Zeiss SMS GmbH, Jena, Germany
}

Correspondence to: F. Rohrer (f.rohrer@fz-juelich.de) and Y. H. Zhang (yhzhang @pku.edu.cn)

Received: 5 April 2012 - Published in Atmos. Chem. Phys. Discuss.: 27 April 2012

Revised: 8 January 2013 - Accepted: 15 January 2013 - Published: 25 January 2013

\begin{abstract}
Measurements of ambient $\mathrm{OH}$ and $\mathrm{HO}_{2}$ radicals were performed by laser induced fluorescence (LIF) during CAREBeijing2006 (Campaigns of Air Quality Research in Beijing and Surrounding Region 2006) at the suburban site Yufa in the south of Beijing in summer 2006. On most days, local air chemistry was influenced by aged air pollution that was advected by a slow, almost stagnant wind from southern regions. Observed daily concentration maxima were in the range of $(4-17) \times 10^{6} \mathrm{~cm}^{-3}$ for $\mathrm{OH}$ and $(2-24) \times 10^{8} \mathrm{~cm}^{-3}$ for $\mathrm{HO}_{2}$ (including an estimated interference of $25 \%$ from $\mathrm{RO}_{2}$ ). During daytime, $\mathrm{OH}$ reactivities were generally high $\left(10-30 \mathrm{~s}^{-1}\right)$ and mainly contributed by observed VOCs and their calculated oxidation products. The comparison of modelled and measured $\mathrm{HO}_{\mathrm{x}}$ concentrations reveals a systematic underprediction of $\mathrm{OH}$ as a function of NO. A large discrepancy of a factor 2.6 is found at the lowest NO concentration encountered $(0.1 \mathrm{ppb})$, whereas the discrepancy becomes insignificant above $1 \mathrm{ppb}$ NO. This study extends similar observations from the Pearl-River Delta (PRD) in South China to a more urban environment. The $\mathrm{OH}$ discrepancy at Yufa can be resolved, if NO-independent additional $\mathrm{OH}$ recycling is assumed in the model. The postulated Leuven Isoprene Mechanism (LIM) has the potential to explain the gap between modelled and measured $\mathrm{OH}$ at Beijing taking
\end{abstract}

into account conservative error estimates, but lacks experimental confirmation. This and the hereby unresolved discrepancy at PRD suggest that other VOCs besides isoprene might be involved in the required, additional $\mathrm{OH}$ recycling. Fast primary production of $\mathrm{RO}_{\mathrm{x}}$ radicals up to $7 \mathrm{ppbh}^{-1}$ was determined at Beijing which was dominated by the photolysis of $\mathrm{O}_{3}, \mathrm{HONO}, \mathrm{HCHO}$, and dicarbonyls. For a special case, 20 August, when the plume of Beijing city was encountered, a missing primary $\mathrm{HO}_{\mathrm{x}}$ source (about $3 \mathrm{ppbh}^{-1}$ ) was determined under high $\mathrm{NO}_{\mathrm{x}}$ conditions similar to other urban areas like Mexico City. CAREBeijing2006 emphasizes the important role of OVOCs as a radical source and sink, and the need for further investigation of the chemical degradation of VOCs in order to better understand radical chemistry in VOC-rich air.

\section{Introduction}

The anthroposphere and biosphere emit huge amounts of trace gases such as $\mathrm{CO}, \mathrm{SO}_{2}, \mathrm{NO}_{\mathrm{x}}$, and volatile organic compounds (VOCs) into the lower troposphere (Finlayson-Pitts and Pitts Jr., 2000; Monks et al., 2009). After emission, these trace gases are removed mainly through chemical oxidation,

Published by Copernicus Publications on behalf of the European Geosciences Union. 
initiated by reactions with hydroxyl radicals $(\mathrm{OH})$, on time scales ranging from minutes to years. Therefore, the selfcleansing capability of the atmosphere is controlled by the concentration of OH (Ehhalt, 1999; Lawrence et al., 2001). The large turnover rates and the concentration of $\mathrm{OH}$ are sustained by cyclic chain reactions depending on the concentrations of VOCs and $\mathrm{NO}_{\mathrm{x}}$, and solar radiation. The framework of these radical chain reactions can be described in general terms by initiation, propagation, and termination processes. Reactions (R1)-(R3) represent the major known initiation reactions, which produce radicals $\mathrm{OH}$ or $\mathrm{HO}_{2}$ through the photolysis of stable compounds.

$$
\begin{aligned}
\mathrm{O}_{3}+h v(\lambda<340 \mathrm{~nm})+\mathrm{H}_{2} \mathrm{O} & \rightarrow 2 \mathrm{OH}+\mathrm{O}_{2} \\
\mathrm{HONO}+h v(\lambda<400 \mathrm{~nm}) & \rightarrow \mathrm{OH}+\mathrm{NO} \\
\mathrm{HCHO}+h v(\lambda<340 \mathrm{~nm})+2 \mathrm{O}_{2} & \rightarrow 2 \mathrm{HO}_{2}+\mathrm{CO}
\end{aligned}
$$

The following chain-propagation Reactions (R4)-(R8) provide an effective interconversion of $\mathrm{OH}, \mathrm{HO}_{2}, \mathrm{RO}_{2}$, and $\mathrm{RO}$ radicals. These reactions involve $\mathrm{CO}$

$\mathrm{OH}+\mathrm{CO}+\mathrm{O}_{2} \rightarrow \mathrm{HO}_{2}+\mathrm{CO}_{2}$

and different VOCs which undergo a similar scheme of reactions

$$
\begin{aligned}
\mathrm{OH}+\mathrm{VOC}_{i}+\mathrm{O}_{2} & \rightarrow \text { products }+\alpha_{i} \mathrm{HO}_{2}+\left(1-\alpha_{i}\right) \mathrm{RO}_{2}(\mathrm{R}) \\
\mathrm{RO}_{2}+\mathrm{NO} & \rightarrow \beta_{i} \mathrm{RO}+\beta_{i} \mathrm{NO}_{2}+\left(1-\beta_{i}\right) \mathrm{RONO}_{2} \\
\mathrm{RO}+\mathrm{O}_{2} & \rightarrow \gamma_{i} \mathrm{HO}_{2}+\left(1-\gamma_{i}\right) \mathrm{RO}_{2}+\mathrm{OVOCs}
\end{aligned}
$$

A major conversion step from $\mathrm{HO}_{2}$ to $\mathrm{OH}$ is provided through reactions with $\mathrm{NO}$ and $\mathrm{O}_{3}$

$$
\begin{aligned}
\mathrm{HO}_{2}+\mathrm{NO} & \rightarrow \mathrm{OH}+\mathrm{NO}_{2} \\
\mathrm{HO}_{2}+\mathrm{O}_{3} & \rightarrow \mathrm{OH}+2 \mathrm{O}_{2}
\end{aligned}
$$

However, the latter being not important in this study even at lower NO levels. Reactions (R5)-(R7) are overall reactions each comprising several elementary radical reactions. The coefficients $\alpha_{i}$ and $\gamma_{i}$ denote fractional yields of $\mathrm{HO}_{2}$, and $\beta_{i}$ denotes the yield of RO. The index $i$ denotes the different VOCs for which the yields can differ substantially (e.g. between alkanes and aromatics). The radicals are finally destroyed by chain-termination reactions with $\mathrm{NO}_{2}$, or by recombination reactions of peroxy radicals, as well as organic nitrate formation (included in the lumped Reaction R6),

$$
\begin{aligned}
\mathrm{OH}+\mathrm{NO}_{2}+\mathrm{M} & \rightarrow \mathrm{HNO}_{3}+\mathrm{M} \\
\mathrm{HO}_{2}+\mathrm{HO}_{2}+(\mathrm{M}) & \rightarrow \mathrm{H}_{2} \mathrm{O}_{2}+\mathrm{O}_{2}+(\mathrm{M}) \\
\mathrm{RO}_{2}+\mathrm{HO}_{2} & \rightarrow \mathrm{ROOH}+\mathrm{O}_{2}
\end{aligned}
$$

In the $\mathrm{OH}-\mathrm{HO}_{2}-\mathrm{RO}_{2}$ reaction cycle, reactions of peroxy radicals with NO (Reactions R6 and R8) followed by photolysis of $\mathrm{NO}_{2}$ (Reaction R13) constitute the exclusive formation pathway for ozone in the troposphere.

$\mathrm{NO}_{2}+h v(\lambda<420 \mathrm{~nm})+\mathrm{O}_{2} \rightarrow \mathrm{NO}+\mathrm{O}_{3}$
Oxygenated VOCs (OVOCs) produced in the oxidation of VOCs (Reactions R5-R7) are precursors of secondary organic aerosols which have been identified to be a major mass fraction of ambient submicron aerosols (Hallquist et al., 2009; Jimenez et al., 2009). Overall, OH and its reaction cycles play a central role in determining gas phase and particle pollution from local to global scales. The description of their concentrations is a key point in atmospheric models addressing questions related to regional pollution and global climate change.

To transfer the theoretical framework of radical chain reactions into atmospheric models, several chemical mechanisms both lumped and nearly explicit have been developed (e.g. Dodge, 2000; Saunders et al., 2003; Jenkin et al., 2003). In previous studies, well established chemical mechanisms like the Regional Atmospheric Chemical Mechanism, RACM (Stockwell et al., 1997), and the Master Chemical Mechanism, MCM (http://mcm.leeds.ac.uk/MCM/; Saunders et al., 2003; Jenkin et al., 2003) were examined in field campaigns including direct measurements of $\mathrm{OH}$ and $\mathrm{HO}_{2}$ (collectively called $\mathrm{HO}_{\mathrm{x}}$ ). The established mechanisms could reproduce observed $\mathrm{OH}$ concentrations in clean air over the Atlantic Ocean (Brauers et al., 2001) and in unpolluted rural areas at low VOC reactivity (e.g. Ehhalt, 1999; Rohrer and Berresheim, 2006). Furthermore, agreement within a factor of two was found between measured and modelled $\mathrm{OH}$ in polluted regions, where atmospheric $\mathrm{NO}_{\mathrm{x}}$ and VOC concentrations were both high. Examples are large cities like Tokyo (Kanaya et al., 2007), New York City, and Houston (Ren et al., 2003; Mao et al., 2010), and the strongly populated Pearl River Delta (PRD) in Southern China (Hofzumahaus et al., 2009; Lu et al., 2012). However, measured OH was significantly underpredicted by models by up to a factor of ten in VOC-rich air in forests (Tan et al., 2001; Ren et al., 2008; Lelieveld et al., 2008; Pugh et al., 2010; Whalley et al., 2011) and in PRD at conditions with low $\mathrm{NO}_{\mathrm{x}}$ (Hofzumahaus et al., 2009). The strong underprediction of $\mathrm{OH}$ is probably caused by a missing $\mathrm{OH}$ recycling mechanism in the models, which is independent of NO. It has been speculated that the missing recycling is related to isoprene (e.g. Lelieveld et al., 2008; Ren et al., 2008; Paulot et al., 2009; Peeters et al., 2009; Peeters and Müller, 2010; Whalley et al., 2011; Lu et al., 2012), but a consistent chemical mechanism explaining the measured concentrations of both $\mathrm{OH}$ and $\mathrm{HO}_{2}$ has not been identified so far (Crounse et al., 2011; Whalley et al., 2011; Lu et al., 2012; Kanaya et al., 2012).

In summer 2006, a field campaign was carried out in Beijing in China to investigate the $\mathrm{HO}_{\mathrm{x}}$ chemistry at transient urban-rural conditions. The campaign followed directly after the above mentioned field study in PRD (Hofzumahaus et al., 2009; Lu et al., 2012) and was part of the Campaigns of Air Quality Research in Beijing and Surrounding Regions 2006 (CAREBeijing2006). Beijing, the capital city of China and one of the largest cities worldwide, is experiencing severe air pollution characterized by high $\mathrm{O}_{3}$ and particulate 
Table 1. Performance of the measurements of $\mathrm{HO}_{\mathrm{x}}$ radicals and related photochemical parameters used in this study.

\begin{tabular}{|c|c|c|c|c|c|}
\hline Parameter & Technique & Accuracy $(1 \sigma)$ & $\operatorname{LOD}^{\mathrm{a}}(1 \sigma)$ & Platform $^{b}$ & Sampling period (2006) \\
\hline $\mathrm{OH}$ & $\mathrm{LIF}^{\mathrm{c}}$ & $20 \%$ & $6 \times 10^{5} \mathrm{~cm}^{-3}$ & CT & 18 Aug-7 Sep \\
\hline $\mathrm{HO}_{2}^{* \mathrm{~d}}$ & $\mathrm{LIF}^{\mathrm{c}}$ & $20 \%$ & $1.5 \times 10^{6} \mathrm{~cm}^{-3}$ & $\mathrm{CT}$ & 18 Aug-7 Sep \\
\hline$k_{\mathrm{OH}}^{2}$ & LP-LIF & $7 \%+0.3 \mathrm{~s}^{-1}$ & $<1 \mathrm{~s}^{-1}$ & $\mathrm{CT}$ & 19 Aug-8 Sep \\
\hline $\mathrm{j}$-values & $\mathrm{SR} / \mathrm{FR}^{\mathrm{f}}$ & $10 \%$ & - & $\mathrm{BR}+\mathrm{CT}$ & 8 Aug-10 Sep \\
\hline $\mathrm{O}_{3}$ & UV photometry & $5 \%$ & $0.3 \mathrm{ppb}$ & $\mathrm{BR}+\mathrm{CT}$ & 2 Aug-10 Sep \\
\hline NO & Chemiluminescence & $7 \%$ & $25 \mathrm{ppt}$ & $\mathrm{BR}$ & 13-31 Aug \\
\hline $\mathrm{NO}_{2}$ & Chemiluminescence & $13 \%$ & $80 \mathrm{ppt}$ & $\mathrm{BR}$ & 13-31 Aug \\
\hline $\mathrm{CO}$ & IR photometry & $5 \%$ & $4 \mathrm{ppb}$ & $\mathrm{BR}$ & 13 Aug-10 Sep \\
\hline HONO & LOPAPg & $10 \%$ & $7 \mathrm{ppt}$ & $\mathrm{CT}$ & 14 Aug-7 Sep \\
\hline $\mathrm{C}_{2}-\mathrm{C}_{10} \mathrm{HCs}$ & GC-FID/PID ${ }^{h}$ & $10 \%$ & $1-90 \mathrm{ppt}$ & $\mathrm{BR}$ & 15 Aug-7 Sep \\
\hline
\end{tabular}

a Limit of detection, the referred time resolution for $\mathrm{HCs}$ measurements are $30 \mathrm{~min}$, the others are $5 \mathrm{~min} ;{ }^{\mathrm{b}} \mathrm{CT}$ : containers, BR: building roof;

${ }^{\mathrm{c}}$ Laser Induced Fluorescence; ${ }^{\mathrm{d}}$ The measurement contains a contribution by $\mathrm{RO}_{2}$, see details in the text; ${ }^{\mathrm{e}}$ Laser flash Photolysis - Laser Induced

Fluorescence; the tested measurement range is $0-190 \mathrm{~s}^{-1}$; ${ }^{\mathrm{f}}$ Spectral Radiometer/Filter Radiometer; ${ }^{\mathrm{g}}$ LOng-Path Absorption Photometry;

${ }^{\mathrm{h}}$ Gas Chromatography Flame-Ionization Detector/Photo-Ionization Detector.

matter (PM) concentrations (Parrish and Zhu, 2009; Shao et al., 2006; Wang et al., 2006). Moreover, as characterized by satellite observations (Richter et al., 2005) and regional models (e.g. Streets et al., 2007), the air pollution in Beijing is also connected to emissions from a number of other neighboring cities extending to eastern central China. A number of field measurements were conducted to characterize the general concentration levels and variabilities of primary (e.g. $\mathrm{SO}_{2}, \mathrm{CO}$, dust and soot particles) and secondary pollutants (e.g. $\mathrm{O}_{3}$, secondary aerosols) in Beijing (Chan and Yao, 2008; Shao et al., 2006; Lu et al., 2010; Wang et al., 2006). CAREBeijing2006 was the first field study that also included detailed measurements of $\mathrm{OH}, \mathrm{HO}_{2}$ and $\mathrm{OH}$ reactivity in Beijing. In this work, we present the summertime $\mathrm{HO}_{\mathrm{x}}$ observations in Beijing, analyze the radical bugets of $\mathrm{HO}_{\mathrm{x}}$, and test how well chemical box models simulate the observed $\mathrm{OH}$ at conditions with high VOC reactivities over a broad range of NO concentrations. The findings will be compared to results from other urban field studies.

\section{Methodology}

\subsection{Experimental}

The measurements analyzed in this paper took place at a suburban rural site $\left(116.3055^{\circ} \mathrm{E}, 39.5145^{\circ} \mathrm{N}\right)$ in Beijing from August to early September in 2006. The site was located on the campus of Beijing Huangpu College in Yufa town, about $40 \mathrm{~km}$ south of the Beijing downtown area. Yufa has a population of about 47000 people (2006) and is surrounded by agricultural fields and small residential villages. There are several small streets within $500 \mathrm{~m}$ distance to the measurement site and a highway (Jingkai) located $1.5 \mathrm{~km}$ in eastern direction. A small forest is lying $2 \mathrm{~km}$ in south-eastern direction and a small factory $1 \mathrm{~km}$ in the South. During the field campaign, the prevailing wind came mostly from southern directions at slow (sometimes stagnant) wind speeds (Fig. 1, upper panel) transporting aged pollution to the measurement site (see Sect. 3.1). Occasionally, northerly winds brought air with freshly emitted pollutants from the city centre of Beijing. The weather was generally characterized by relatively high humidities with water-vapor mixing ratios of $1-3 \%$ and temperatures of about $19-32^{\circ} \mathrm{C}$ during the campaign.

Two sampling platforms were set up within $30 \mathrm{~m}$ distance at the Yufa site. One platform $\left(\mathrm{HO}_{\mathrm{x}}\right.$ platform) was on top of two stacked sea-containers at $7 \mathrm{~m}$ above ground, where $\mathrm{OH}, \mathrm{HO}_{2}$, total $\mathrm{OH}$ reactivity $\left(k_{\mathrm{OH}}\right), \mathrm{HONO}, \mathrm{O}_{3}, j\left(\mathrm{O}^{1} \mathrm{D}\right)$, $j\left(\mathrm{NO}_{2}\right)$, and local temperature and wind were measured. The other platform was located on top of a four-story school building $15 \mathrm{~m}$ above ground, where $\mathrm{NO}_{\mathrm{x}}, \mathrm{NO}_{\mathrm{y}}, \mathrm{O}_{3}, \mathrm{HONO}$, hydrocarbons ( $\mathrm{HCs}), \mathrm{CO}, \mathrm{SO}_{2}$, solar actinic radiation, and meteorological parameters (R. M. Young Company, Michigan, USA) were determined. Technical specifications of the measured quantities are listed in Table 1. A summary of typical atmospheric-chemical conditions is given in Table 2 listing mean values for the morning (06:00-10:00 CNST, $\mathrm{CNST}=$ Chinese Standard Time $=\mathrm{UTC}+8 \mathrm{~h}$ ) and afternoon (12:00-16:00 CNST) hours. The table also distinguishes between conditions for southerly wind and, represented by 20 August, for northerly wind directions (numbers in parentheses). Detailed information about physical and chemical properties of aerosols measured simultaneously to the gas phase composition can be found in Garland et al. (2009); Cheng et al. (2009); Achtert et al. (2009); Wiedensohler et al. (2009); Takegawa et al. (2009).

\subsubsection{OH, $\mathrm{HO}_{2}$, and $k_{\mathrm{OH}}$}

The concentrations of $\mathrm{OH}$ and $\mathrm{HO}_{2}$ were measured by a compact laser-induced fluorescence (LIF) system constructed at Forschungszentrum Jülich with identical setup to the PRIDEPRD2006 campaign (Lu et al., 2012). The radicals in ambient 


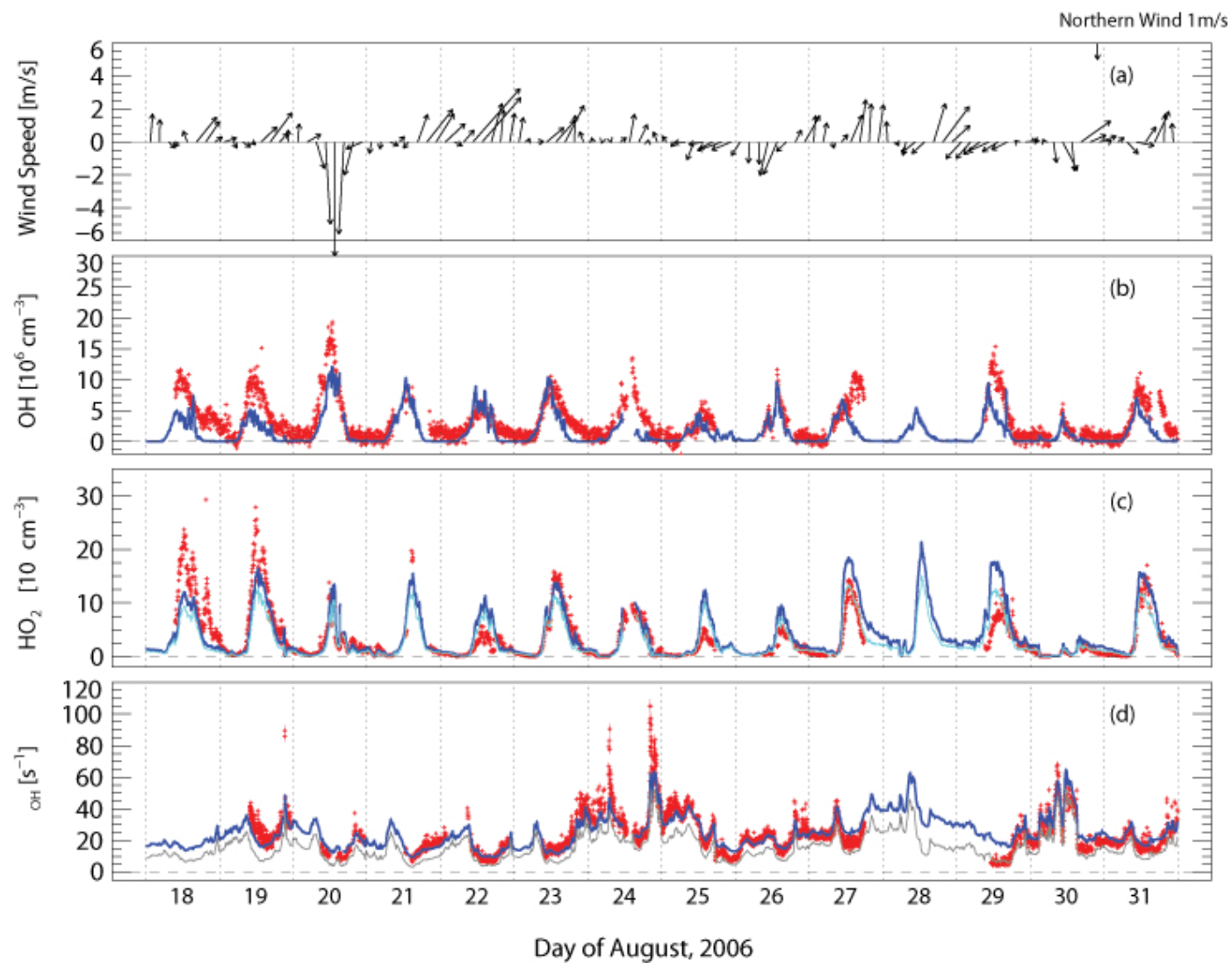

Fig. 1. Time series of $\mathrm{OH}, \mathrm{HO}_{2}, \mathrm{HO}_{2}^{*}, \mathrm{OH}$ reactivity, and local wind at the Yufa site during the CAREBeijing2006 campaign. Panel (a): local wind direction and speed. Panel (b)-(d): experimental values of $\mathrm{OH}, \mathrm{HO}_{2}^{*}$ and $\mathrm{OH}$ reactivity denoted by red symbols; corresponding model (M0) results are given by blue lines. Panel (c): the cyan line shows modelled $\mathrm{HO}_{2}$ concentrations. Panel (d): the grey line represents $\mathrm{OH}$ reactivities derived from measured $\mathrm{OH}$ reactant concentrations. Vertical dotted lines denote midnight.

air were sampled by gas expansion into two separated lowpressure (3.5 mbar) fluorescence cells running in parallel. Each cell sampled a flow of $1 \mathrm{slm}$ (standard litre per minute, at $298 \mathrm{~K}$ and $1 \mathrm{~atm}$ ) of air through a $0.4 \mathrm{~mm}$ inlet nozzle and was additionally purged by a pure nitrogen flow with $1.2 \mathrm{slm}$ ( $1 \mathrm{slm}$ sheath flow through the cell, $0.2 \mathrm{slm}$ through the laser baffle arms). In the first cell for $\mathrm{OH}$ detection, $\mathrm{OH}$ radicals were electronically excited by tunable pulsed UV laser radiation at a $8.5 \mathrm{kHz}$ repetition rate at a wavelength of $308 \mathrm{~nm}$. The laser system consisted of an intracavity frequencydoubled tunable dye-laser (Tintura, New Laser Generation) which was pumped by a frequency-doubled Nd:YAG laser (Navigator, Spectra Physics). The resulting $\mathrm{OH}$ resonance fluorescence was detected by time-delayed gated photon counting. In the second cell for $\mathrm{HO}_{2}$ detection, a small flow of $1 \mathrm{sccm}$ NO was added to the sampled air flow. As a result, $\mathrm{HO}_{2}$ was converted to $\mathrm{OH}$ by reaction with $\mathrm{NO}$, followed by LIF detection of $\mathrm{OH}$. The measurement system was calibrated using the photolysis of water vapor in synthetic air at $185 \mathrm{~nm}$ as a source of $\mathrm{OH}$ and $\mathrm{HO}_{2}$. The averaged sensitivities derived from all the calibrations were used to convert the detected fluorescence signals into concentrations. Dur- ing the campaign, the $1 \sigma$ reproducibility of the $\mathrm{OH}$ and $\mathrm{HO}_{2}$ calibration measurements were $3.1 \%$ and $20.2 \%$, respectively. The estimated precisions of $\mathrm{OH}$ and $\mathrm{HO}_{2}$ for $5 \mathrm{~min}$ integration time were about $0.04 \times[\mathrm{OH}]+6 \times 10^{5} \mathrm{~cm}^{-3}$ and $0.08 \times\left[\mathrm{HO}_{2}\right]+1 \times 10^{7} \mathrm{~cm}^{-3}$, respectively.

Recently, Fuchs et al. (2011) discovered a significant interference in our $\mathrm{HO}_{2}$ detection system resulting from partial conversion of peroxy radicals from alkenes, isoprene and aromatics through their reaction with NO. Therefore, the measured $\mathrm{HO}_{2}$ concentration is a lumped parameter including both ambient $\mathrm{HO}_{2}$ and diverse contributions from ambient $\mathrm{RO}_{2}$ radicals as shown by Eq. (1), hereafter denoted as $\mathrm{HO}_{2}^{*}$. Relative detection sensitivities $\left(\alpha_{\mathrm{RO}_{2}}^{i}\right)$ applicable to our instrument can be found in Lu et al. (2012).

$\left[\mathrm{HO}_{2}^{*}\right]=\left[\mathrm{HO}_{2}\right]+\Sigma\left(\alpha_{\mathrm{RO}_{2}}^{i} \times\left[\mathrm{RO}_{2}\right]_{i}\right)$

Atmospheric $\mathrm{OH}$ reactivity, $k_{\mathrm{OH}}$, was determined as the inverse chemical $\mathrm{OH}$ lifetime by a new module based on the above LIF system (Lou et al., 2010). Ambient air was drawn continuously through a laminar flow tube with $20 \mathrm{slm}$ and exposed to short UV laser pulses (266 nm, $10 \mathrm{~ns}$ ) from a frequency-quadrupled $\mathrm{Nd}$ :YAG laser running at a pulse 
Table 2. Mean values of photolysis frequencies and trace gas concentrations during morning (06:00-10:00 CNST) and afternoon (12:00-16:00 CNST) hours for days with southerly wind when measurement data for $\mathrm{OH}$ and $k_{\mathrm{OH}}$ were simultaneously available. Data from days with northern wind (represented by 20 August) are given in parenthesis.

\begin{tabular}{|c|c|c|}
\hline \multirow[t]{2}{*}{ Parameter } & \multicolumn{2}{|c|}{ Mean Value } \\
\hline & 06:00-10:00 & 12:00-16:00 \\
\hline $\mathrm{O}_{3}(\mathrm{ppb})$ & $15(17)$ & $76(51)$ \\
\hline NO (ppb) & $8.6(7.3)$ & $0.15(1.6)$ \\
\hline $\mathrm{NO}_{2}(\mathrm{ppb})$ & $19.2(24.0)$ & $2.0(6.1)$ \\
\hline HONO (ppb) & $0.8(0.8)$ & $0.3(0.4)$ \\
\hline $\mathrm{CO}(\mathrm{ppb})$ & $920(640)$ & $650(230)$ \\
\hline $\mathrm{ETH}^{*}(\mathrm{ppb})$ & $4.8(4.5)$ & $4.5(4.2)$ \\
\hline $\mathrm{HC}^{*}(\mathrm{ppb})$ & $5.1(3.5)$ & $1.7(0.3)$ \\
\hline $\mathrm{HC}^{*}(\mathrm{ppb})$ & $3.4(2.8)$ & $1.7(0.6)$ \\
\hline $\mathrm{HC} 8 *(\mathrm{ppb})$ & $1.4(1.1)$ & $0.7(0.7)$ \\
\hline ETE* $^{*}(\mathrm{ppb})$ & $4.0(3.9)$ & $3.1(2.7)$ \\
\hline $\mathrm{OLT}^{*}(\mathrm{ppb})$ & $4.0(1.7)$ & $1.7(0.2)$ \\
\hline OLI* (ppb) & $0.3(0.2)$ & $0.01(0.01)$ \\
\hline DIEN* $^{*}(\mathrm{ppb})$ & $0.2(0.3)$ & $0.01(0.00)$ \\
\hline $\mathrm{ISO}^{*}(\mathrm{ppb})$ & $0.4(1.1)$ & $0.8(0.7)$ \\
\hline $\mathrm{TOL}^{*}(\mathrm{ppb})$ & $5.8(5.5)$ & $1.8(0.6)$ \\
\hline $\mathrm{XYL}^{*}(\mathrm{ppb})$ & $0.8(0.5)$ & $0.1(0.0)$ \\
\hline $\mathrm{H}_{2} \mathrm{O}(\%$ abs $)$ & $2.2(2.3)$ & $2.1(1.7)$ \\
\hline$k_{\mathrm{OH}}\left(\mathrm{s}^{-1}\right)$ & $25.5(14.9)$ & $17.4(9.5)$ \\
\hline \multicolumn{3}{|c|}{ Photolysis frequencies $\left(\mathrm{s}^{-1}\right)$} \\
\hline $\mathrm{O}_{3} \rightarrow \mathrm{O}^{1} \mathrm{D}$ & $0.6(0.7) \times 10^{-5}$ & $1.6(1.8) \times 10^{-5}$ \\
\hline $\mathrm{NO}_{2} \rightarrow \mathrm{NO}+\mathrm{O}$ & $3.4(3.3) \times 10^{-3}$ & $5.8(5.5) \times 10^{-3}$ \\
\hline $\mathrm{HONO} \rightarrow \mathrm{NO}+\mathrm{OH}$ & $5.7(5.6) \times 10^{-4}$ & $9.7(9.3) \times 10^{-4}$ \\
\hline $\mathrm{HCHO} \rightarrow \mathrm{H}_{2}+\mathrm{CO}$ & $1.3(1.2) \times 10^{-5}$ & $2.3(2.2) \times 10^{-5}$ \\
\hline $\mathrm{HCHO} \rightarrow \mathrm{H}+\mathrm{HCO}$ & $1.0(1.0) \times 10^{-5}$ & $1.8(1.9) \times 10^{-5}$ \\
\hline Temperature $\left({ }^{\circ} \mathrm{C}\right)$ & $23.1(27.7)$ & $28.7(30.0)$ \\
\hline Pressure $(\mathrm{hPa})$ & $1003(1003)$ & $1003(1003)$ \\
\hline
\end{tabular}

* See VOC assignment in Table 3.

repetition rate of $0.5-1 \mathrm{~Hz}$. OH radicals $\left(\sim 10^{9} \mathrm{~cm}^{-3}\right)$ were generated by laser-flash photolysis of $\mathrm{O}_{3}$ and the subsequent $\mathrm{OH}$ decay in the sampled air was probed by a third fluorescence cell. $k_{\mathrm{OH}}$ for ambient air was finally retrieved from numerical curve fits to the observed $\mathrm{OH}$ decays with zeroair decays subtracted. The accuracy $\left(10 \%+0.3 \mathrm{~s}^{-1}\right)$ of the instrument was evaluated before and after the campaign using air mixtures (e.g. $\mathrm{CO}$ in synthetic air) of known reactivities in the range of $0-190 \mathrm{~s}^{-1}$. The precision of the derived $k_{\mathrm{OH}}$ value is about $4-10 \%$ for typical integration times of 1-3 min.

\subsubsection{Photolysis frequencies}

$j\left(\mathrm{O}^{1} \mathrm{D}\right)$ and $j\left(\mathrm{NO}_{2}\right)$ were measured by two filter radiometers $(\mathrm{FR})$ on the $\mathrm{HO}_{\mathrm{x}}$ platform. In parallel, a spectroradiometer (SR) measured spectra of solar actinic flux densities on the school building at a greater height. The photolysis frequencies derived from the spectroradiometer mea- surements showed very good correlations $\left(r^{2}>0.999\right)$ with the FR measurements, but are systematically larger by $9 \%$. The smaller values of the FR instruments were caused by a nearby building shielding part of the sky radiation. For the interpretation of the $\mathrm{HO}_{\mathrm{x}}$ dataset, the photolysis frequencies of $\mathrm{HCHO}$ and HONO derived from the SR spectra were scaled down by $9 \%$ to represent the conditions at the measurement position of the $\mathrm{HO}_{\mathrm{x}}$ instrument. The instruments measured only the downwelling part of the actinic flux. The upwelling contribution was neglected because the ground albedo in the UV range is typically small $(<10 \%)$, in particular over paved ground and vegetated areas (Feister and Grewe, 1995; McKenzie and Kotkamp, 1996). All radiometers were calibrated with a PTB-traceable irradiance standard and a reference instrument before and after the campaign (Bohn et al., 2008).

\subsection{3 $\mathrm{O}_{3}, \mathrm{NO}_{\mathrm{x}}, \mathrm{CO}, \mathrm{HONO}$}

Ozone was measured simultaneously by three in-situ UVabsorption photometers. Instruments from Thermo Electron (model 49C/TEI) and Ecotech (model EC9810B) were operated by Tokyo-Ibaraki University (UT-IU) and Peking University (PKU), with the inlets located on top of the school building. An ozone photometer from Environment $\mathrm{SA}$ (model $\mathrm{O}_{3}-41 \mathrm{M}$ ) was run by Forschungszentrum Jülich (FZJ) with the sampling inlet close to the inlets of the $\mathrm{HO}_{\mathrm{x}}$ instrument. For the interpretation of the $\mathrm{HO}_{\mathrm{x}}$ dataset, the FZJ dataset was chosen. A regression analysis of all three ozone data sets shows good agreement $\left(r^{2}>0.9\right)$, with less than $5 \%$ deviation of the regression-line slopes from unity. In order to achieve complete time coverage, data gaps in the FZJ time series were filled with scaled data from the UT-IU and PKU instruments.

$\mathrm{NO}$ and $\mathrm{NO}_{2}$ were measured by two chemiluminescence measurement systems on top of the school building. The first system, a model 42CTL from a Thermo Electron, was operated by UT-IU and used a photolytical reactor (Droplet Measurement Technologies, Model BLC) for conversion of $\mathrm{NO}_{2}$ to NO (Takegawa et al., 2009). The other chemiluminescence instrument (model EC9841B by Ecotech) applied a molybdenum oxide converter for $\mathrm{NO}_{2}$ to $\mathrm{NO}$ conversion. Given the low NO concentrations $(\approx 0.2 \mathrm{ppb})$ during afternoon hours at Yufa and the relatively low detection sensitivity of the Ecotech instrument (LOD $\approx 0.5 \mathrm{ppb}$ at 1 min time resolution for $\mathrm{NO}$ ), and the potential of the molybdenum converter for interferences by non- $\mathrm{NO}_{\mathrm{x}}$ reactive nitrogen species (Dunlea et al., 2007), the data set of UT-IU was used for the present work. Minor data gaps were, however, filled with scaled data from the PKU instrument. The use of measured NO data for the interpretation of $\mathrm{HO}_{\mathrm{x}}$ data collected $30 \mathrm{~m}$ apart assumes that there was no significant NO gradient between the two measurement platforms. The relatively smooth timeseries of the observed NO concentrations and the good agreement of the $\mathrm{O}_{3}$ concentrations observed at both platforms suggests 
Table 3. Measured hydrocarbons and their assignment to RACM-MIM-GK species.

\begin{tabular}{ll}
\hline RACM & Observed hydrocarbons from Online GC \\
\hline ETH & Ethane \\
ETE & Ethene \\
HC3 & Propane, $i$-Butane, $n$-Butane \\
HC5 & Cyclopentane, $i$-Pentane, $n$-Pentane, 2-Methylpentane, 3-Methylpentane, \\
& 2,4-Dimethylpentane, $n$-Hexane, 2,2,4-Trimethylpentane \\
HC8 & $n$-Heptane, Cyclohexane, 2-Methylhexane, 3-Methylhexane, $n$-Octane, \\
& 2-Methylheptane, 3-Methylheptane, $n$-Nonane, Methylcyclohexane \\
OLT & Propene, 1-Butene, $i$-Butene, 1-Pentene, 3-Methylbutene \\
OLI & trans-2-Butene, cis-2-Butene, trans-2-Pentene, cis-2-Pentene \\
DIEN & 1,3-Butadiene \\
ISO & Isoprene \\
TOL & Benzene, Toluene, Ethylbenzene, $i$-Propylbenzene, $n$-Propylbenzene \\
XYL & $m, p$-Xylene, $o$-Xylene, Styrene, 1,3,5-Trimethylbenzene, \\
& $1,2,4$-Trimethylbenzene, $1,2,3$-Trimethylbenzene, $p$-Ethyltoluene \\
\hline
\end{tabular}

uniformly mixed air around the two platforms. Furthermore, measurements of submicron aerosols gave no hints for significant local combustion sources that would co-emit NO, except that particles were detected at night probably as part of diesel emissions from a highway at $1.2 \mathrm{~km}$ distance east of the Yufa site (Takegawa et al., 2009).

$\mathrm{CO}$ measurements were obtained on top of the school building by a non-dispersive infrared absorption analyzer (NDIR, model 48C from Thermo Electron) with an integration time of $1 \mathrm{~min}$. Air samples were dried before measurement in order to avoid the interference from water vapor. A detailed description of the $\mathrm{CO}$ instruments can be found in Takegawa et al. (2009).

$\mathrm{HONO}$ was measured on the $\mathrm{HO}_{\mathrm{x}}$ platform by a two channel in-situ long-path absorption photometer (LOPAP) which is a modified commercial instrument (QUMA, Wuppertal) (Li et al., 2012; Heland et al., 2001). The documented interferences like $\mathrm{NO}_{2}, \mathrm{NO}, \mathrm{HNO}_{3}$, PAN, etc known for ambient HONO measurements were removed by the second channel of this LOPAP instrument which is shown by extensive laboratory investigations (cf. Table 2 of Heland et al., 2001) and intercomparsion to DOAS measurements (Kleffmann et al., 2006). The measurement of HONO with a second instrument on the other platform showed good agreement within $15 \%$ and a high correlation of the data sets $\left(r^{2}=0.84\right)$ suggesting no significant concentration gradient between the measurement platforms.

\subsubsection{Hydrocarbons}

Continuous measurements of HC species (Table 4) were performed with a time resolution of $30 \mathrm{~min}$ by two online gaschromatographic (GC) systems with flame ionization (FID) and photo ionization (PID) detectors (Syntech Spectra GC-FID/PID GC955 series 600/800 VOC analyzer). Calibration was performed using a gas standard before and after the campaign. The standard contained target species with mixing ratios of $1 \mathrm{ppm}$ in nitrogen, prepared with a gravimetric method (Spectra gases, Restek Corporation, USA). More details of the GC system are given by Xie et al. (2008).

\subsection{Model}

A box model was applied to simulate the concentrations of $\mathrm{OH}, \mathrm{HO}_{2}, \mathrm{HO}_{2}^{*}$, unmeasured secondary compounds, and $k_{\mathrm{OH}}$ at the Yufa field site. The model was constrained by observed photolysis frequencies, $\mathrm{O}_{3}, \mathrm{NO}, \mathrm{NO}_{2}, \mathrm{CO}, \mathrm{HONO}, \mathrm{C}_{2}-\mathrm{C}_{10}$ hydrocarbons (Table 4 ), water vapor, temperature and pressure. The model uses the chemical mechanism RACM-MIMGK, which is derived from the Regional Atmospheric Chemistry Mechanism (RACM; Stockwell et al., 1997) by additional implementation of a condensed version of the Mainz Isoprene Mechanism (MIM; Pöschl et al., 2000) by Geiger et al. (2003) and Karl et al. (2006). A detailed documentation of RACM-MIM-GK has been given by $\mathrm{Lu}$ et al. (2012). In the present work, we have additionally included newly discovered reactions that recycle $\mathrm{OH}$ without NO. We have added (i) reactions of carbonyl peroxy radicals $\left(\mathrm{R}(\mathrm{C}=\mathrm{O}) \mathrm{R}^{\prime} \mathrm{O}_{2}\right.$ ) with $\mathrm{HO}_{2}$ producing $\mathrm{OH}$ (Jenkin et al., 2007; Dillon and Crowley, 2008) and (ii) the isoprene epoxide chemistry by Paulot et al. (2009) as described in Lu et al. (2012). Both enhancements resulted in only small changes of the $\mathrm{HO}_{\mathrm{x}}$ system for the boundary conditions used for Beijing and for PRD when compared to the previously used RACMMIM-GK mechanism (Hofzumahaus et al., 2009; Lu et al., 2012). The resulting base scenario denoted as M0 is assumed to represent the current knowledge of atmospheric chemistry in the lower troposphere. As a benchmark test (M5), model calculations were also performed using the new MCM version $3.2(\mathrm{MCMv} 3.2$; http://mcm.leeds.ac.uk/MCM/). The revised MCM contains laboratory-based improvements, for example updates of the chemistry of methacrolein (MACR) 
Table 4. Box model simulations examined for the CAREBeijing2006 dataset

\begin{tabular}{|c|c|}
\hline Simulation & Description \\
\hline M0 & $\begin{array}{l}\text { RACM-MIM-GK, plus OH recycling from (i) reactions of acyl and } \beta \text {-keto per- } \\
\text { oxy radicals with } \mathrm{HO}_{2} \text { (Jenkin et al., 2007, 2010; Dillon and Crowley, 2008), } \\
\text { and (ii) isoprene epoxide formation (Paulot et al., 2009) }\end{array}$ \\
\hline M1 & $\begin{array}{l}\mathrm{M} 0 \text {, plus radical recycling from } \mathrm{RO}_{2}+\mathrm{X} \rightarrow \mathrm{HO}_{2} \text { and } \mathrm{HO}_{2}+\mathrm{X} \rightarrow \mathrm{OH} \\
\text { (Hofzumahaus et al., 2009) }\end{array}$ \\
\hline M2 & M0, plus radical recycling from $\mathrm{HO}_{2}+\mathrm{Y} \rightarrow \mathrm{OH}(\mathrm{Lu}$ et al., 2012) \\
\hline M3a & $\begin{array}{l}\text { M0, plus LIM0 scheme with a yield of three OH radicals from the photolysis of } \\
\text { HPALDs (Peeters and Müller, 2010) }\end{array}$ \\
\hline M3b & $\begin{array}{l}\text { M3a, but with a factor of } 50 \text { reduced isomerization rate of isoprene peroxy } \\
\text { radicals (Crounse et al., 2011) }\end{array}$ \\
\hline M4 & $\begin{array}{l}\text { M0, plus MIM2 }{ }^{+} \text {scheme with a yield of four OH radicals from the reaction of } \\
\text { ISOP }+\mathrm{HO}_{2} \text { (Lelieveld et al., 2008; Butler et al., 2008) }\end{array}$ \\
\hline M5 & $\mathrm{MCMv} 3.2$ \\
\hline M6 & M0, plus a primary $\mathrm{OH}$ source $Q(\mathrm{OH})$ \\
\hline M7 & M0, plus a primary $\mathrm{HO}_{2}$ source $Q\left(\mathrm{HO}_{2}\right)$ \\
\hline
\end{tabular}

and isoprene-derived hydroperoxides and nitrates, and in particular the above mentioned $\mathrm{OH}$ recycling mechanisms (i) and (ii).

All model runs were performed in a time-dependent mode with two days spin-up. A $24 \mathrm{~h}$ lifetime (Lu et al., 2012) was introduced for all modelled species to account for dry deposition losses. The lifetime corresponds to an assumed deposition velocity of $1.2 \mathrm{~cm} \mathrm{~s}^{-1}$ and a well-mixed boundary layer height of about $1 \mathrm{~km}$. The height agrees with measurements of $0.8-1.2 \mathrm{~km}$ obtained by a LIDAR instrument at PKU in Beijing (X. Liu, personal communication, 2012). Numerical sensitivity tests show that the assumed deposition lifetime has a relatively small influence on the reactivity of the modelled oxidation products (e.g. OVOCs). As a result, calculated $\mathrm{OH}$ and $\mathrm{HO}_{2}$ concentrations vary by less than $5 \%$ and $10 \%$, respectively, if the deposition rate is changed by a factor of two. This result is similar to the findings by Lou et al. (2010) and Lu et al. (2012) for the PRD campaign. The total error of the base model (M0) is estimated to be about $40 \%$ for $\mathrm{OH}, \mathrm{HO}_{2}$, and $\mathrm{HO}_{2}^{*}$. It is composed of an error of $10-20 \%$ caused by the uncertainty of the reaction rate constants in the model, less than $10 \%$ by the assumed deposition lifetime (see above), and $20 \%$ from experimentally determined boundary conditions like measured VOCs, CO, $\mathrm{NO}_{\mathrm{x}}$ and photolysis frequencies. For further details see the supplementary materials of Lu et al. (2012). An extended discussion of the model uncertainties caused by unconstrained calculated OVOCs is given in Sect. 3.4.

\section{Results}

\subsection{Time series of observed and modelled $\mathrm{HO}_{\mathrm{x}}$ concentrations and $k_{\mathrm{OH}}$}

Observations and base model results (M0) for $\mathrm{OH}, \mathrm{HO}_{2}^{*}$ and $k_{\mathrm{OH}}$ are presented together with local wind data for the time period 18-31 August 2006 in Fig. 1. Additional $\mathrm{HO}_{\mathrm{x}}$ data measured during 1-7 September 2006 are given in the Supplement (Fig. S1), but no corresponding model results are available for this time period due to lack of supporting data (e.g. $\mathrm{NO}, \mathrm{NO}_{2}, \mathrm{CO}$ ). Measurements of important trace gases and photolysis frequencies related to the $\mathrm{HO}_{\mathrm{x}}$ data are given in Fig. 2.

Observed $\mathrm{OH}$ and $\mathrm{HO}_{2}^{*}$ concentrations showed distinct diurnal variations with daily maximum values around noontime. Peak concentrations for $\mathrm{OH}$ and $\mathrm{HO}_{2}^{*}$ were in the range of (4-17) $\times 10^{6} \mathrm{~cm}^{-3}$ and $(2-24) \times 10^{8} \mathrm{~cm}^{-3}$, respectively. In parallel, high $k_{\mathrm{OH}}$ values of $10-30 \mathrm{~s}^{-1}$ during daytime and up to $105 \mathrm{~s}^{-1}$ at nighttime were observed. Chemical removal rates of ambient trace gases, estimated by the product $[\mathrm{OH}] \times k_{\mathrm{OH}}$, reached on average maximum values of $25 \mathrm{ppb} \mathrm{h}^{-1}$ at noon, indicating large photochemical activity.

The $\mathrm{OH}$ concentrations calculated by the base model (M0) show similar temporal variations as the measured data, but with a general tendency to underpredict the observed $\mathrm{OH}$ in the afternoon. This behaviour coincides mostly with southerly wind directions. In contrast, good agreement of modelled and measured $\mathrm{OH}$ is seen in the afternoon on days that were influenced by northerly winds (e.g. 20, 26 and 30 August). Observed nighttime $\mathrm{OH}$ concentrations were generally underestimated for both wind conditions. In case of $\mathrm{HO}_{2}^{*}$, the model captures the observed concentrations reasonably well within the experimental uncertainties (see 

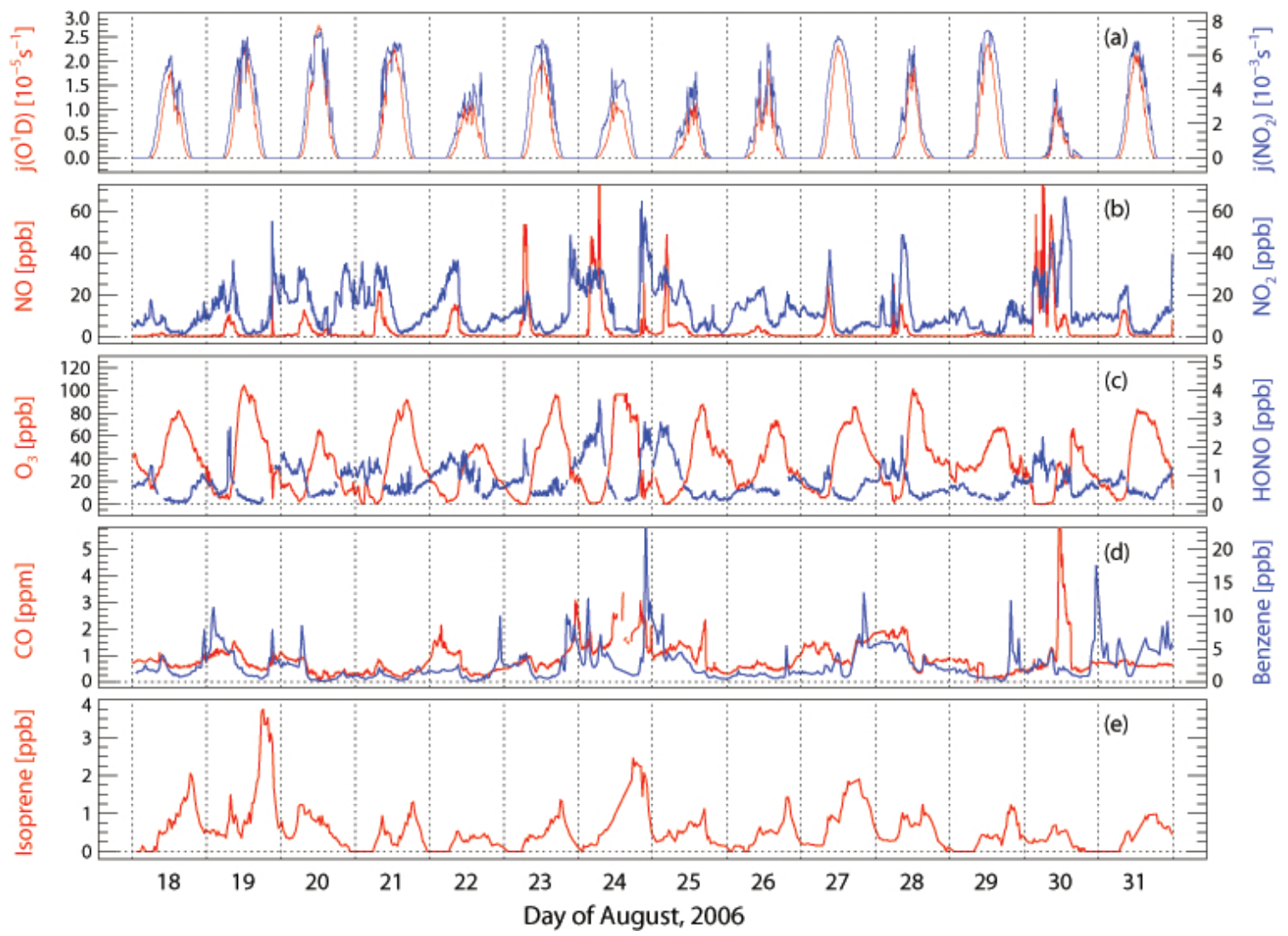

Fig. 2. Time series of measured $j\left(\mathrm{O}^{1} \mathrm{D}\right), j\left(\mathrm{NO}_{2}\right), \mathrm{NO}_{\mathrm{x}}, \mathrm{O}_{3}, \mathrm{HONO}, \mathrm{CO}$, benzene, isoprene at the Yufa site during the CAREBeijing2006 campaign. On 24 August, the ozone data were clipped by the data acquisition system at a value of $100 \mathrm{ppb}$.

Sect. 2.1), independent of the wind direction. The robust agreement of measured and modelled $\mathrm{HO}_{2}$ which contrasts the behaviour of $\mathrm{OH}$ is discussed in Sect. 4.3.1. Relatively small differences are calculated between $\mathrm{HO}_{2}$ and $\mathrm{HO}_{2}^{*}$. On average, the difference is about $30 \%$ in the morning and $20 \%$ in the afternoon.

The measured $\mathrm{OH}$ reactivity, $k_{\mathrm{OH}}$, is about a factor of two larger than the reactivity calculated from all measured trace gases, indicating a large fraction of unmeasured atmospheric components. In fact, OVOCs including formaldeyhde were not measured at the Yufa field site and are likely the main cause for the missing reactivity. This assumption is supported by the good agreement of modelled (M0) and observed $k_{\mathrm{OH}}$ on most days (except 29 August). Apparently, the model calculates generally adequate amounts of OVOCs to explain the gap between the reactivity calculated from the measured trace gases and the experimental $k_{\mathrm{OH}}$. The modelled (M0) concentration of HCHO, one of the major calculated OVOCs, is on average $10-15 \mathrm{ppb}$ at daytime. These values are well situated in the range (5-25 ppb) characterized by other groundbased measurements performed in summer at Beijing ( $\mathrm{Li}$ et al., 2010; Gong et al., 2010). At our site, boundary-layer averaged $\mathrm{HCHO}$ concentrations of about $6 \mathrm{ppb}$ were determined remotely by multi-axis differential optical absorption spectroscopy (MaxDOAS) for a few days (18, 19, 21, 27, 29, 31 August) (Li et al., 2012). Compared to the reported HCHO measurements (Li et al., 2010, 2012; Gong et al., 2010), the modelled (M0) concentrations of HCHO appear reasonable for this region and time of the year.

The OH reactivity on 29 August is overpredicted by the model by about a factor of 2.5 with contributions of $40 \%$ from measured compounds and $60 \%$ from modelled OVOCs. It possibly indicates an unaccounted fast loss process of the modelled OVOCs on this particular day. Precipitation was noticed in the morning of 29 August (Takegawa et al., 2009) that may have led to a reduction of soluble reactive species. Another possible reason could be fresh local emissions of VOCs that were less photochemically aged than implicitly assumed in the model. Thus, ambient OVOC concentrations would be smaller than the steady-state concentrations produced in the model run.

In order to better understand the diurnal behaviour of $\mathrm{OH}$ at different wind directions, it is useful to compare the air composition for southerly and northerly winds (see Table 2 and Fig. S2). In general, the air was much more polluted in the morning than in the afternoon hours on all days. For example, in the morning the concentrations of $\mathrm{NO}$ and $\mathrm{NO}_{2}$ were on average $7-8 \mathrm{ppb}$ and $20 \mathrm{ppb}$, respectively. On the 
days with prevailing southerly winds, $\mathrm{NO}_{\mathrm{x}}$ decreased dramatically towards the afternoon, reaching typically $0.15 \mathrm{ppb}$ $\mathrm{NO}$ and $2 \mathrm{ppb} \mathrm{NO}_{2}$. On the days with northerly wind (here represented by 20 August since other northerly wind days had large data gaps in the measurements of $\mathrm{HO}_{\mathrm{x}}$ or trace gases), the decrease of $\mathrm{NO}_{\mathrm{x}}$ was much smaller in the afternoon. As a result, $\mathrm{NO}$ and $\mathrm{NO}_{2}$ were still about $1.6 \mathrm{ppb}$ and $6 \mathrm{ppb}$, respectively. At the same time, afternoon values of $\mathrm{CO}$ and hydrocarbons were 3-10 times smaller on $20 \mathrm{Au}-$ gust compared to the other days. The levels of $\mathrm{O}_{3}$, isoprene, photolysis frequencies, temperature and pressure were comparable for both wind directions. In general, we can note that good model-to-measurement agreement of $\mathrm{OH}$ is found at conditions with elevated $\mathrm{NO}_{\mathrm{x}}$ concentrations, while large discrepancies occurred when NO was smaller than $1 \mathrm{ppb}$, i.e. during afternoon hours at southerly winds.

The two wind directions are the result of an anticyclonic system that controlled the weather during the field campaign (Matsui et al., 2009). Regarding the northerly wind period, a cold front passage brought clean air from the northern mountainous region with entrained fresh emissions from Beijing city through strong northerly winds. In this case, our measurements characterized the outflow of Beijing city mixed with mountainous air. The elevated afternoon NO on $20 \mathrm{Au}-$ gust probably originated from traffic emissions as shown by correspondingly elevated soot particle concentrations (Garland et al., 2009). During the periods with southerly wind, air was mainly transported from highly industrialized regions from the North China Plain at low wind speeds. Due to the stagnant wind conditions, enhanced concentrations of secondary aerosols were observed during this period in Beijing City and Yufa (Takegawa et al., 2009; Garland et al., 2009; Gunthe et al., 2011), indicating photochemically aged air from the South. This is consistent with regional model simulations showing aged air pollution in the South of Beijing that had accumulated over large distances of several hundred kilometers (Matsui et al., 2009).

\subsection{Experimental determination of the $\mathrm{OH}$ budget}

The $\mathrm{OH}$ radical is a highly reactive species with a lifetime of less than $1 \mathrm{~s}$ in the troposphere. Its concentration reaches steady state within seconds. Thus, modelled $\mathrm{OH}$ concentrations at a $5 \mathrm{~min}$ timescale can be expressed at moderate and high NO concentrations by Eq. (2), where $P(\mathrm{OH})$ denotes the primary production rate of $\mathrm{OH}$ from radical initiation processes.

$$
[\mathrm{OH}]=\frac{P(\mathrm{OH})+k_{8}\left[\mathrm{HO}_{2}\right][\mathrm{NO}]}{k_{4}[\mathrm{CO}]+\Sigma k_{5 i}\left[\mathrm{VOC}_{i}\right]+k_{10}[\mathrm{M}]\left[\mathrm{NO}_{2}\right]}
$$

According to this equation, the comparison of modelled and observed $\mathrm{OH}$ concentrations is a test whether the model can describe correctly the ratio of the production and destruction terms of $\mathrm{OH}$. In case of model-measurement disagreement, it is not directly evident whether a problem occurs in the modelling of the production or destruction terms. Furthermore, agreement of measured and modelled $\mathrm{OH}$ does not necessarily imply a correct model, because systematic errors in the production and destruction terms may have cancelled out fortuitously. Therefore, it is additionally useful to examine directly the balance of the production and destruction terms of $\mathrm{OH}$ with experimental measurements, expressed by Eq. (3) (Hofzumahaus et al., 2009).

$[\mathrm{OH}] \times k_{\mathrm{OH}}=P(\mathrm{OH})+k_{8}\left[\mathrm{HO}_{2}\right][\mathrm{NO}]$

In the present work, we calculate the terms on the left and right hand sides of the equation, using measured $\mathrm{OH}, k_{\mathrm{OH}}$, $\mathrm{HO}_{2}^{*}$ and NO. $P(\mathrm{OH})$ has been calculated for reactions $\mathrm{R} 1$ and $\mathrm{R} 2$ from measured $\mathrm{O}_{3}, \mathrm{H}_{2} \mathrm{O}, \mathrm{HONO}$ and corresponding photolysis frequencies. We note that using $\mathrm{HO}_{2}^{*}$ instead of $\mathrm{HO}_{2}$ leads to a systematic overestimation of the $\mathrm{OH}$ production rate from the $\mathrm{HO}_{2}$ to $\mathrm{OH}$ recycling. The error is about 20-30\% due to the difference between $\mathrm{HO}_{2}^{*}$ and $\mathrm{HO}_{2}$ estimated by the base model (see previous section).

By applying this method, the diurnal variations of the $\mathrm{OH}$ budget were analyzed for the southerly wind days (we use a subset of southerly wind days in which all required measurements are simultaneously available over full diurnal cycles - 19, 23, 27 and 31 August) and for 20 August in Fig. 3a and $b$. The two panels show the diurnal profiles of the total $\mathrm{OH}$ loss rate (red line), the total production rate using $\mathrm{HO}_{2}^{*}$ (blue line), and the corrected production rate using model (M0) corrected $\mathrm{HO}_{2}$ (cyan line). A strong imbalance indicating a missing $\mathrm{OH}$ source up to $17 \mathrm{ppbh}^{-1}$ is determined for the afternoon hours of the southerly wind days using $\mathrm{HO}_{2}^{*}$. In the morning hours of the southerly wind days, the total $\mathrm{OH}$ production rate based on $\mathrm{HO}_{2}^{*}$ is larger than the loss rate. After correction of the $\mathrm{HO}_{2}$ interference, the $\mathrm{OH}$ budget becomes well balanced in the morning, whereas the need for a large additional $\mathrm{OH}$ source in the afternoon remains. Regarding 20 August (Fig. 3b), the experimentally determined $\mathrm{OH}$ budget is found to be balanced throughout this day. Based on the observed $\mathrm{HO}_{2}^{*}$ concentration, the calculated $\mathrm{OH}$ production rate is slightly larger than the $\mathrm{OH}$ loss rate, but the discrepancy disappears mostly when the $\mathrm{HO}_{2}$ measurement is corrected.

A significant $\mathrm{OH}$ imbalance with the $\mathrm{OH}$ production rate being larger than the measured loss rate has been reported by Mao et al. (2010) for the morning rush hours in Houston, Mexico City and New York City, while a balanced budget was observed at other times of the day. They noted that the $\mathrm{OH}$ imbalance in the morning maybe related to the model underprediction of their $\mathrm{HO}_{2}$ measurements in the morning, but found no explanation for these results. It is possible that both of their observations, the $\mathrm{OH}$ imbalance and the underpredicted $\mathrm{HO}_{2}$ in the morning were caused by a similar $\mathrm{HO}_{2}$ interference like in our case, since their $\mathrm{HO}_{2}$ detection method also relies on chemical conversion with NO. As another explanation Dusanter et al. (2009) suggested that the OH imbalance could be a consequence of segregation. The segregation phenomenon would reduce the reaction rate between $\mathrm{HO}_{2}$ 

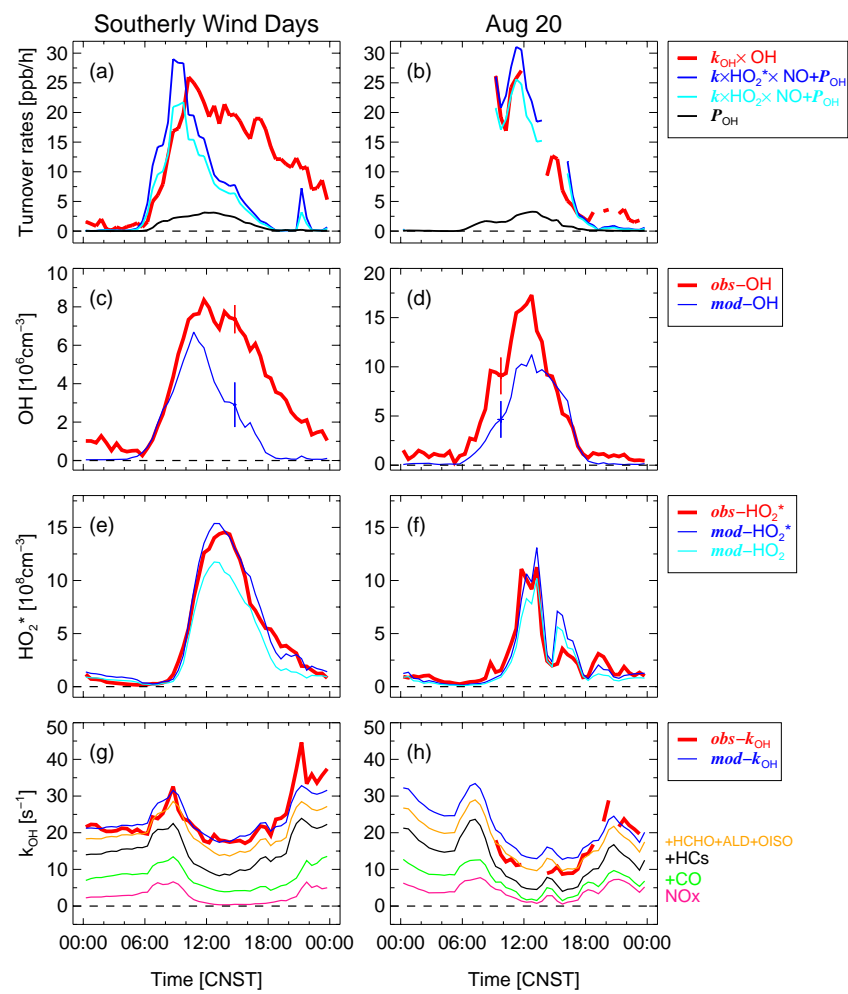

Fig. 3. Mean diurnal profiles of $\mathrm{OH}$ turnover rates $(\mathbf{a}, \mathbf{b})$, concentrations of $\mathrm{OH}(\mathbf{c}, \mathbf{d})$ and $\mathrm{HO}_{2}^{*}(\mathbf{e}, \mathbf{f})$, and $\mathrm{OH}$ reactivities $(\mathbf{g}, \mathbf{h})$ on days with southerly (19, 23, 27 and 31 August, left column) and northerly wind (20 August; right column). Experimental and modelled (M0) data are shown as red and blue lines, respectively. Panels $(\mathbf{c}, \mathbf{d})$ : the vertical bars represent $1 \sigma$ errors. Panels $(\mathbf{e}, \mathbf{f})$ : the cyan lines show modelled $\mathrm{HO}_{2}$. Panels $(\mathbf{g}, \mathbf{h})$ : in addition to total $k_{\mathrm{OH}}$, contributions from measured $\mathrm{NO}_{\mathrm{x}}, \mathrm{CO}$, hydrocarbons (Table 3) and modelled $\mathrm{HCHO}+\mathrm{ALD}+\mathrm{OISO}$ are cumulatively shown.

and NO when the air mass is not well mixed. In our case, a reduction of the effective reaction rate by $25-65 \%$ would be needed, indicating extremely inhomogeneous air masses. This seems unrealistic at the Yufa field site, because no large local NO emission sources were detected.

The results of the experimental $\mathrm{OH}$-budget analysis are consistent with the comparison of the modelled and measured radical concentrations. As the NO concentration and major parts of $P(\mathrm{OH})$ in $\mathrm{M} 0$ are fixed to observed values, the simultaneous comparison of measured and modelled $\mathrm{OH}$, $\mathrm{HO}_{2}^{*}$, and $k_{\mathrm{OH}}$ provides another approach to investigate the $\mathrm{OH}$ budget. Figure $3 \mathrm{c}$ shows that the model can reproduce the mean observed $\mathrm{OH}$ at high $\mathrm{NO}_{\mathrm{x}}$ in the morning until about 11:00 CNST, but strongly underestimates the $\mathrm{OH}$ measurements by up to a factor of 2.5 at 12:00-16:00 in the presence of low $\mathrm{NO}_{\mathrm{x}}$. On the other hand, the $\mathrm{HO}_{2}^{*}$ concentrations are well described within their measurement errors throughout the whole day (Fig. 3e). Even the modelled $\mathrm{HO}_{2}$ concentrations are close to the observed $\mathrm{HO}_{2}^{*}$, which implies that the $\mathrm{OH}$ production from the reaction of $\mathrm{HO}_{2}$ with $\mathrm{NO}$ is well captured by the model. This and the good agreement of the measured and modelled $k_{\mathrm{OH}}$ (Fig. $3 \mathrm{~g}$ ) demonstrate, that the underprediction of $\mathrm{OH}$ during the afternoon is caused by a missing $\mathrm{OH}$ source in the base model. This finding applies to conditions at low $\mathrm{NO}_{\mathrm{x}}$ (cf. Fig. S2) and large $\mathrm{OH}$ reactivities (about $20 \mathrm{~s}^{-1}$ ) dominated by VOCs (Fig. $3 \mathrm{~g}$ ).

On 20 August, the situation is more complicated. The experimentally determined $\mathrm{OH}$ production and destruction rates are well balanced (Fig. 3b). Nevertheless, the model underestimates the measured $\mathrm{OH}$ concentrations significantly by up to a factor of two in the morning and around noontime, while agreement is found in the afternoon (Fig. 3d). At all times, $\mathrm{NO}_{\mathrm{x}}$ is relatively high $(8-30 \mathrm{ppb})$. The modelled diurnal profiles of $\mathrm{HO}_{2}^{*}$ and $\mathrm{HO}_{2}$ both agree well with the observed $\mathrm{HO}_{2}^{*}$ (Fig. 3f). Around noontime, the measured $\mathrm{OH}$ reactivity is overestimated by the base model, which may partly explain the underestimated $\mathrm{OH}$. This observation is further investigated in Sect. 4.3.2.

\section{3 $\mathrm{RO}_{\mathrm{x}}$ budget in the base case model (M0)}

Primary production and termination rates of $\mathrm{RO}_{\mathrm{x}}(=\mathrm{OH}$ $+\mathrm{HO}_{2}+\mathrm{RO}_{2}$ ) radicals are analyzed in Fig. 4. Corresponding values of $\mathrm{NO}_{\mathrm{x}}, \mathrm{O}_{3}$ and the partitioning of the $\mathrm{OH}$ reactivity from observed hydrocarbons can be found in Fig. S2 as Supplement. Overall, relatively fast radical production rates $P\left(\mathrm{RO}_{\mathrm{x}}\right)$, up to $7 \mathrm{ppbh}^{-1}$, are calculated by the base model for days with southerly wind and 20 Aug. During daytime, $P\left(\mathrm{RO}_{\mathrm{x}}\right)$ was dominated by the photolysis of HONO $(24 \%$, $25 \%), \mathrm{O}_{3}(15 \%, 12 \%)$, HCHO $(27 \%, 32 \%)$, and dicarbonyls $(16 \%, 18 \%)$. The latter group is given by the sum of three mechanistic species in RACM, i.e. GLY (glyoxal), MGLY (methylglyoxal and other $\alpha$-carbonyl aldehydes), and DCB (unsaturated dicarbonyls). Here, the italic numbers represent values for southerly wind days and non-italic numbers represent those of 20 August. In general, ozonolysis of alkenes and other photolysis processes contributed only a few percent to $P\left(\mathrm{RO}_{\mathrm{x}}\right)$. In the afternoon, the photolysis rate of $\mathrm{O}_{3}$ was strongly elevated compensating the morning peak contribution from HONO photolysis so that the resulting $P\left(\mathrm{RO}_{\mathrm{x}}\right)$ profile became relatively symmetrical with respect to local noon. Radical production from $\mathrm{NO}_{2}$ photolysis by light in the visible wavelength range as proposed by $\mathrm{Li}$ et al. (2008) was investigated as well. The overall contribution from this channel to $P(\mathrm{ROx})$ during daytime was less than $2 \%$. Moreover, the reaction rate and yield of this mechanism are still under discussion (Carr et al., 2009; Amedro et al., 2011). Thus, this $\mathrm{NO}_{2}$ photolysis channel was not further tested here.

Due to the relatively short lifetime of $\mathrm{RO}_{\mathrm{x}}$ radicals, the total termination rate of $\mathrm{RO}_{\mathrm{x}}, L\left(\mathrm{RO}_{\mathrm{x}}\right)$, was in balance with the fast total primary production rate, $P\left(\mathrm{RO}_{\mathrm{x}}\right)$, in the timedependent model runs. For southerly wind days at noontime, there was a distinct change of the dominating $L\left(\mathrm{RO}_{\mathrm{x}}\right)$ channel from $\mathrm{RO}_{\mathrm{x}}+\mathrm{NO}_{\mathrm{x}}$ to $\mathrm{RO}_{\mathrm{x}}+\mathrm{HO}_{\mathrm{x}}$ reactions. For 20 August, the $\mathrm{RO}_{\mathrm{x}}+\mathrm{NO}_{\mathrm{x}}$ reactions dominated $L\left(\mathrm{RO}_{\mathrm{x}}\right)$ until twilight 


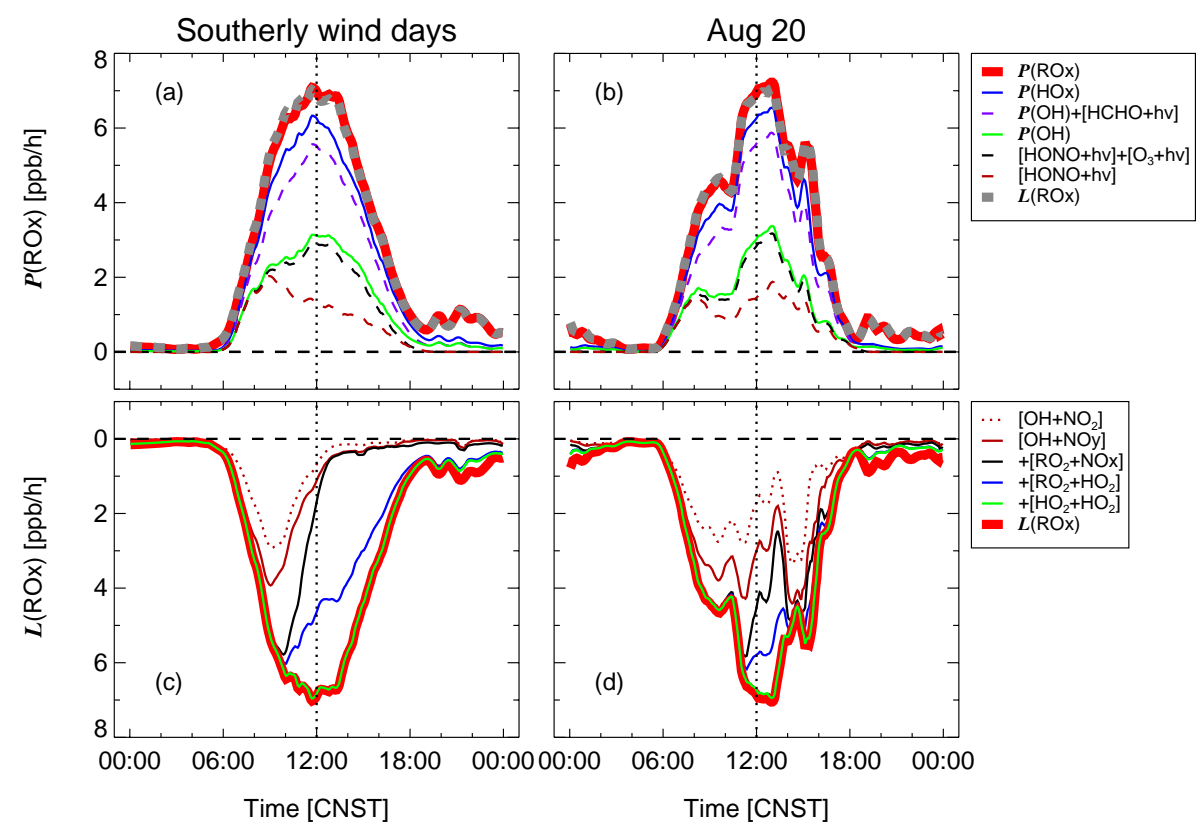

Fig. 4. Production (a, b) and loss rates $(\mathbf{c}, \mathbf{d})$ of $\mathrm{RO}_{\mathrm{x}}\left(=\mathrm{OH}+\mathrm{HO}_{2}+\mathrm{RO}_{2}\right)$ calculated by the base model (M0) for southerly (left column) and northerly wind (20 August; right column). Panels (a, b): breakdown of primary $\mathrm{RO}_{\mathrm{x}}$ production resulting from photolytic processes and ozonolysis. $P(\mathrm{OH}), P\left(\mathrm{HO}_{\mathrm{x}}\right)$, and $P\left(\mathrm{RO}_{\mathrm{x}}\right)$ denote total, primary production rates of $\mathrm{OH}, \mathrm{HO}_{\mathrm{x}}$, and $\mathrm{RO}_{\mathrm{x}}$, respectively. Panels $(\mathbf{c}$, d): cumulative plot of $\mathrm{RO}_{\mathrm{x}}$ losses caused by radical termination reactions. The brown solid line denotes the loss rate by $\mathrm{OH}+\mathrm{NO}_{\mathrm{y}}$, the black solid line by $\mathrm{OH}+\mathrm{NO}_{\mathrm{y}}$ and $\mathrm{RO}_{2}+\mathrm{NO}_{\mathrm{x}}$, etc. The total $\mathrm{RO}_{\mathrm{x}}$ loss rate is given by $L\left(\mathrm{RO}_{\mathrm{x}}\right)$ (also shown in panels $\left.\mathbf{a}, \mathbf{b}\right)$.

conditions due to elevated $\mathrm{NO}_{\mathrm{x}}$ concentrations. For all days, the reaction between $\mathrm{NO}_{2}$ and $\mathrm{OH}$ was the most important $L\left(\mathrm{RO}_{\mathrm{X}}\right)$ channel during morning hours. It contributed about half or more to $L\left(\mathrm{RO}_{\mathrm{x}}\right)$, while the remainder was contributed from the reaction of $\mathrm{NO}+\mathrm{OH}(15 \%, 10 \%)$, the formation of peroxyacyl nitrates $(15 \%, 11 \%)$, and the formation of alkyl nitrates $(8 \%, 6 \%)$. In the afternoon, the recombination of $\mathrm{RO}_{\mathrm{x}}$ radicals made contributions of $34 \%$ from $\mathrm{HO}_{2}+\mathrm{HO}_{2}$ and $56 \%$ from $\mathrm{RO}_{2}+\mathrm{HO}_{2}$ to $L\left(\mathrm{RO}_{\mathrm{x}}\right)$ for the southerly winds days, while those reactions contributed only $33 \%$ ( $=15 \%$ from $\mathrm{HO}_{2}+\mathrm{HO}_{2}$ and $18 \%$ from $\mathrm{RO}_{2}+\mathrm{HO}_{2}$ ) to $L\left(\mathrm{RO}_{\mathrm{x}}\right)$ during afternoon hours on 20 August.

In Fig. 5, the interconversion processes of the $\mathrm{RO}_{\mathrm{x}}$ cycle in $\mathrm{M} 0$ are further analyzed, studying the turnover rates for $\mathrm{OH} \rightarrow \mathrm{HO}_{2}, \mathrm{OH} \rightarrow \mathrm{RO}_{2}, \mathrm{RO}_{2} \rightarrow \mathrm{HO}_{2}$, and $\mathrm{HO}_{2} \rightarrow \mathrm{OH}$. Specific details of $\mathrm{OH}$ loss reactions can also be obtained from the analysis of $k_{\mathrm{OH}}$ in Figs. $3 \mathrm{~g}, 3 \mathrm{~h}$, and Fig. S2. In general, about half of the total $\mathrm{OH}$ loss rate was determined by reactions with measured hydrocarbons and $\mathrm{CO}$, while the other half was determined by daughter products (e.g. HCHO and oxygenated products of isoprene) of measured hydrocarbons for both periods. The oxidation of anthropogenic (e.g. alkenes) and biogenic hydrocarbons (isoprene) showed comparable contributions to the total $\mathrm{OH} \rightarrow \mathrm{RO}_{2}$ rate during southerly wind days while the oxidation of isoprene became the dominant pathway for 20 August.
The $\mathrm{RO}_{2} \rightarrow \mathrm{HO}_{2}$ reaction rate was dominated by NO reactions with peroxy radicals such as MO2 (methyl peroxy radical), MACP (peroxy radicals from methacrolein $+\mathrm{OH}$ ), ISOP (peroxy radicals from isoprene $+\mathrm{OH}$ ), ETEP (peroxy radicals from ethene $+\mathrm{OH}$ ) and OLTP (peroxy radicals from terminal alkenes $+\mathrm{OH}$ ) during southerly wind days, while it was dominated by those involving MO2, MACP, ISOP for 20 August. The $\mathrm{HO}_{2} \rightarrow \mathrm{OH}$ conversion was dominated by the reaction $\mathrm{HO}_{2}+\mathrm{NO}$ at all times. The $\mathrm{HO}_{2} \rightarrow \mathrm{OH}$ conversion rate approximately equals the sum of the production rates of peroxy radicals by $\mathrm{OH}$ reactions, i.e. $R\left(\mathrm{OH} \rightarrow \mathrm{HO}_{2}\right)$ $+R\left(\mathrm{OH} \rightarrow \mathrm{RO}_{2}\right)$, indicating efficient radical recycling. The $\mathrm{OH}$ regeneration by $\mathrm{R}(\mathrm{C}=\mathrm{O}) \mathrm{R}^{\prime} \mathrm{O}_{2}+\mathrm{HO}_{2} \rightarrow \mathrm{OH}$ and the isoprene epoxide chemistry included in the base model have only a marginal impact on the total recycling rates. They contributed up to $2 \%$ for low $\mathrm{NO}_{\mathrm{x}}$ conditions and were fully negligible at high $\mathrm{NO}_{\mathrm{x}}$. Consequently, the influence of these two mechanistic updates for the modelled $\mathrm{HO}_{\mathrm{x}}$ concentrations is marginal. Only a few percent difference is found between the base model (M0) and RACM-MIM-GK, and between MCMv3.2 (M5) and MCMv3.1 (cf. Figs. S3 and S4).

\subsection{Model (M0) uncertainties from unconstrained calculated OVOCs}

In the model simulations of $\mathrm{OH}, \mathrm{HO}_{2}, \mathrm{HO}_{2}^{*}$, and $k_{\mathrm{OH}}$, also OVOCs including $\mathrm{HCHO}$ were calculated by the model. The time-dependent model calculations were initialized with 


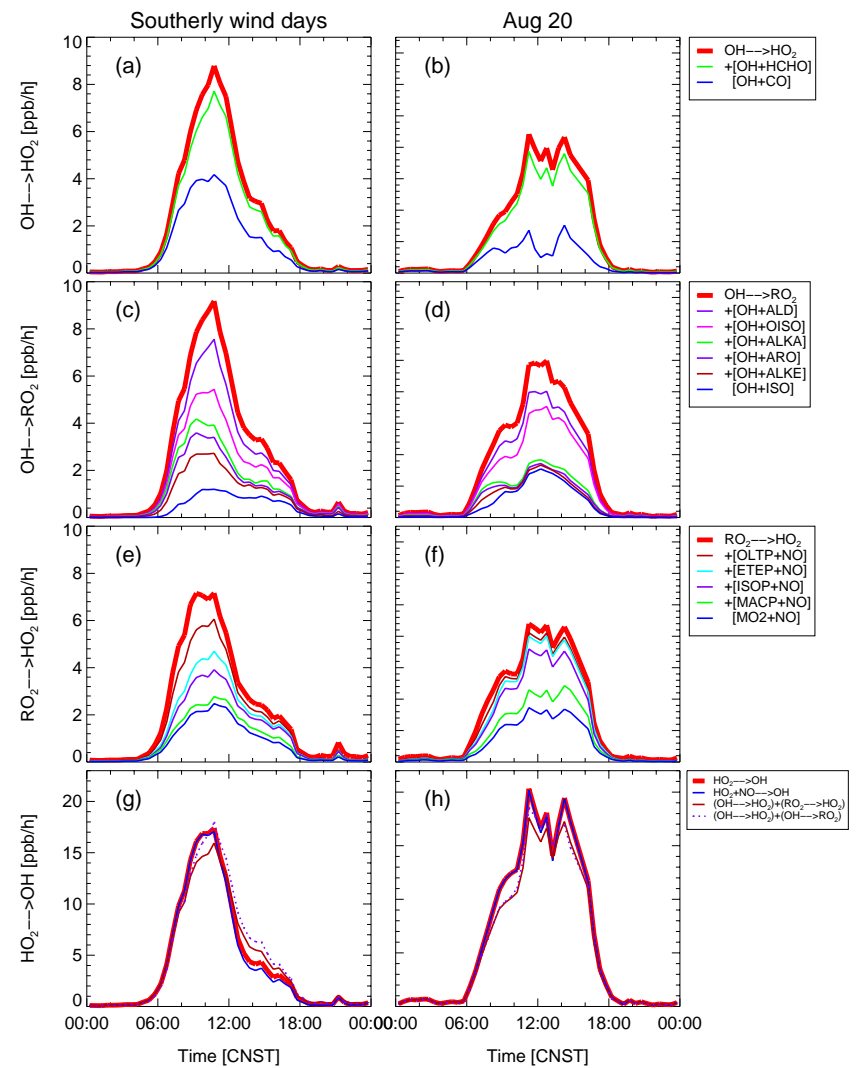

Fig. 5. Radical conversion rates of $\mathrm{OH} \rightarrow \mathrm{HO}_{2}$ (a, b), $\mathrm{OH} \rightarrow \mathrm{RO}_{2}$ (c, d), $\mathrm{RO}_{2} \rightarrow \mathrm{HO}_{2} \quad(\mathbf{e}, \mathbf{f})$, and $\mathrm{HO}_{2} \rightarrow \mathrm{OH} \quad($ g, h), calculated with M0. Cumulative contributions of dominating reactions are presented as explained in Fig. 4. Red solid lines represent the total rates. Panel $(\mathbf{g}, \mathbf{h})$ : the dotted violet and solid brown lines indicate additionally the total $\mathrm{OH}$ loss and $\mathrm{HO}_{2}$ production rates, respectively, both confined to radical conversion reactions.

OVOC concentrations obtained from a 2-day spin-up simulation assuming quasi steady-state for the OVOCs. This procedure assumes that the air mass under investigation was chemically aged and the build-up of long-lived species was limited by deposition. The assumption of an aged air mass was well fulfilled for most days of the campaign characterized by slow, almost stagnant wind from southerly directions (Sect. 3.1). The analysis of the $\mathrm{RO}_{\mathrm{x}}$ budget (Sect. 3.3) and of $k_{\mathrm{OH}}$ (Sect. 3.1) demonstrates that OVOCs played an important role in Yufa both as radical precursors and as $\mathrm{OH}$ reactants. Since OVOCs were not constrained by measurements in the model runs, errors in the calculated OVOC concentrations may significantly impact the modelled results for $\mathrm{OH}$, $\mathrm{HO}_{2}$, and $k_{\mathrm{OH}}$. In order to test the corresponding sensitivities, additional model runs were performed constraining the OVOC time series to half and twice the concentration values calculated in the base model run (M0). Figure 6a-f show the results for southerly wind days when the sensitivity test is applied either for HCHO only, or for all OVOCs. In case
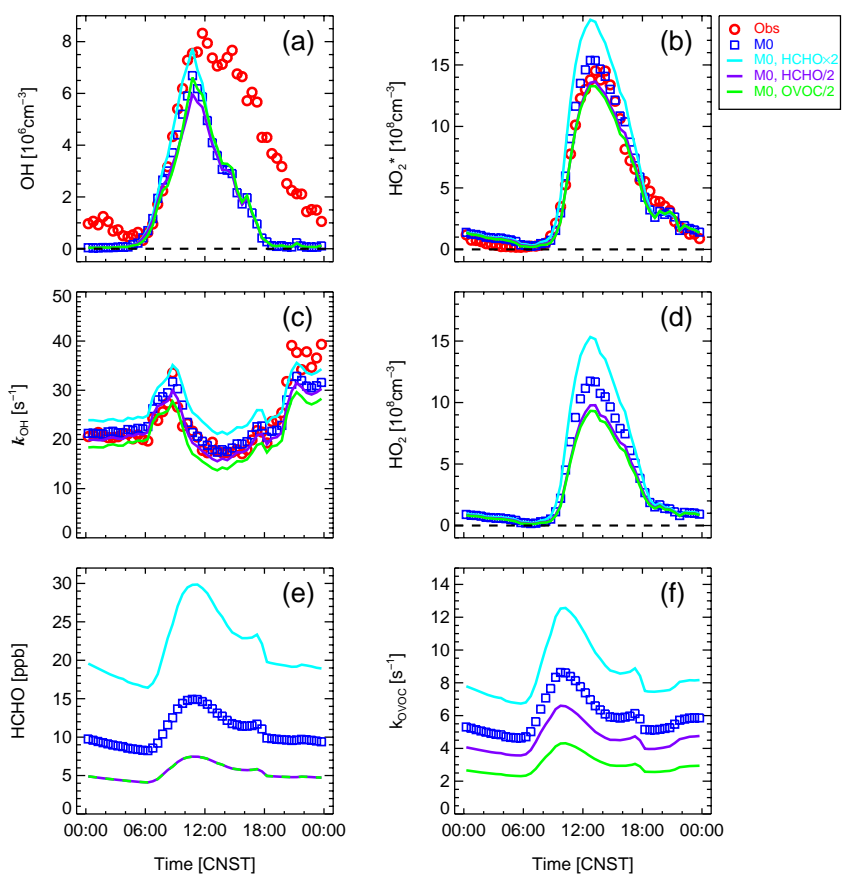

Fig. 6. Comparison of mean diurnal profiles of measured and modelled $\mathrm{OH}(\mathbf{a}), \mathrm{HO}_{2}^{*}(\mathbf{b}), k_{\mathrm{OH}}(\mathbf{c})$ at southerly wind conditions. The modelled data were obtained using different constraints for $\mathrm{HCHO}$ and OVOCs. M0 applies no constraints, whereas the other runs $(\mathrm{HCHO} \times 2, \mathrm{HCHO} / 2, \mathrm{OVOC} / 2)$ are constrained to half or twice the $\mathrm{HCHO} / \mathrm{OVOC}$ concentrations calculated by MO.

of a variation of $\mathrm{HCHO}$ only, the daytime averaged concentrations are about $6 \mathrm{ppb}$ and $24 \mathrm{ppb}$, respectively, well situated at the lower and upper bounds of the previously reported $\mathrm{HCHO}$ concentration range (5-25 ppb) in Beijing ( $\mathrm{Li}$ et al., 2010; Gong et al., 2010). For these boundary conditions, the modelled $\mathrm{OH}$ concentrations prove to be rather insensitive and remain constant within $10 \%$ (Fig. 6a). This low sensitivity can be explained by counteracting effects, i.e. $\mathrm{OH}$ production by photolysis of $\mathrm{HCHO}$ (Reaction R3 followed by R8) is partly compensated by $\mathrm{OH}$ loss through the reaction of $\mathrm{OH}$ with HCHO. The calculated peroxy radical concentrations are more sensitive and vary by $20-30 \%$ (Fig. 6 b, d), while modelled $k_{\mathrm{OH}}$ changes by about $20 \%$ (Fig. $6 \mathrm{c}$ ). Similar results as for $\mathrm{HCHO}$ are obtained when all OVOCs (including $\mathrm{HCHO}$ ) are changed by a factor of two. This demonstrates that the OVOC-related model uncertainties are dominated by $\mathrm{HCHO}$. Overall, the simulated diurnal profiles of $\mathrm{OH}, \mathrm{HO}_{2}$, $\mathrm{HO}_{2}^{*}$ and $k_{\mathrm{OH}}$ prove to be quite robust even for large $\mathrm{OVOC}$ variations. Thus, the general conclusions obtained from the base model run remain valid, i.e. $\mathrm{HO}_{2}^{*}$ and $k_{\mathrm{OH}}$ are resonably well reproduced by the model, while $\mathrm{OH}$ is significantly underpredicted in the afternoon. 

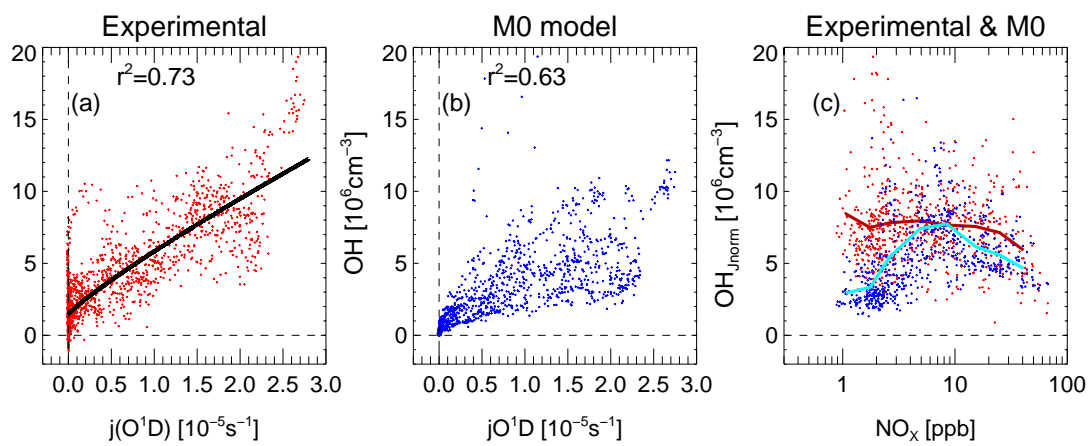

Fig. 7. The $j\left(\mathrm{O}^{1} \mathrm{D}\right)$ and $\mathrm{NO}_{\mathrm{x}}$ dependence of the observed and modelled (M0) OH concentrations. The symbols denote five minute averaged data. In panel (a), a least square fit to Eq. (5) is shown as a solid line. In panel (b) and (c), the $\mathrm{OH}$ data were first selected by $j\left(\mathrm{O}^{1} \mathrm{D}\right)$ $>0.5 \times 10^{-5} \mathrm{~s}^{-1}$ and then normalized to $j\left(\mathrm{O}^{1} \mathrm{D}\right.$ ) (see text), thus denoted as $\mathrm{OH}_{\mathrm{Jnorm}}$. The red and blue solid lines give the averaged values of measured and modelled $\mathrm{OH}_{\mathrm{Jnorm}}$, respectively, over equally spaced $\log \left(\mathrm{NO}_{\mathrm{x}}\right)$ intervals.
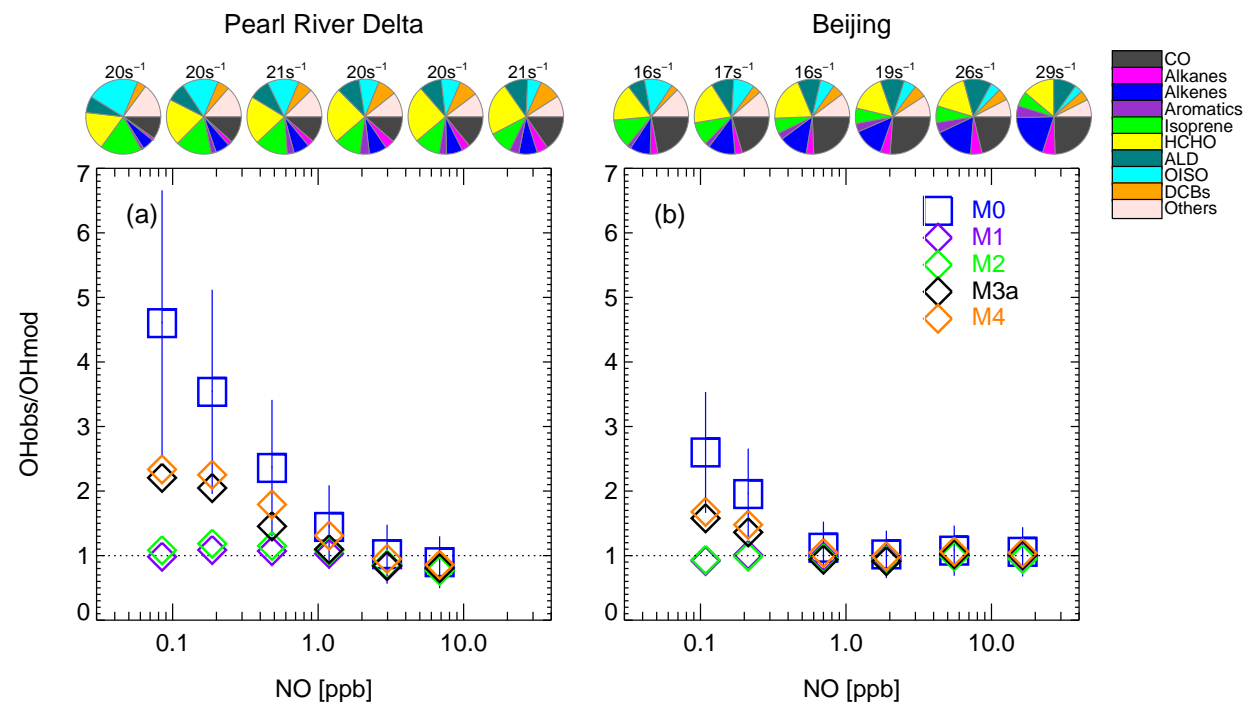

Fig. 8. NO dependence of the observed-to-modelled $\mathrm{OH}$ ratio $\left(\mathrm{OH}_{\mathrm{obs}} / \mathrm{OH}_{\text {mod }}\right)$ for different mechanistic scenarios at Pearl River Delta (Lu et al., 2012) and Beijing, respectively. Vertical error bars denote combined $1 \sigma$ accuracies of the modelled (M0) and observed OH concentrations. Total VOC reactivities (M0 case) and their organic speciation (without $\mathrm{NO}_{\mathrm{x}}$ ) are presented by pie charts at different NO intervals $(\Delta \ln ([\mathrm{NO}] / \mathrm{ppb})=0.17)$ at the top. Abbrev. in the color legend of the pie charts: ALD $=$ higher aldehydes than HCHO, $\mathrm{OISO}=\mathrm{MACR}+\mathrm{MVK}+\mathrm{CAR} 4, \mathrm{DCBs}=\mathrm{MGLY}+\mathrm{GLY}+\mathrm{DCB}$, Others = degradation products from hydrocarbons that exclude HCHO, ALD, OISO, DCBs.

\section{$3.5 j\left(O^{1} \mathrm{D}\right)$ dependence of $\mathrm{OH}$}

Measured $\mathrm{OH}$ and $j\left(\mathrm{O}^{1} \mathrm{D}\right)$ show a high correlation $\left(r^{2}=\right.$ 0.73) (Fig. 7). Following the concept by Toenges-Schuller et al. (2006), the square of the linear correlation coefficient between observed $\mathrm{OH}$ and $j\left(\mathrm{O}^{1} \mathrm{D}\right)$ can be expressed as

$$
\begin{aligned}
& r_{\mathrm{OH}, j\left(\mathrm{O}^{1} \mathrm{D}\right)}^{2}= \\
& \quad\left(1-e_{\mathrm{OH}, \mathrm{OH}}\right)\left(1-e_{j\left(\mathrm{O}^{1} \mathrm{D}\right), j\left(\mathrm{O}^{1} \mathrm{D}\right)}\right) /\left(1-e_{\mathrm{OH}, j\left(\mathrm{O}^{1} \mathrm{D}\right)}\right)^{2}
\end{aligned}
$$

Here, $e_{i, i}$ denotes the relative error variance of a measured parameter $i$ and $e_{i, j}$ represents the covariance of the errors of the two measured parameters $i, j$. According to Eq. (4), the true correlation coefficient between the $\mathrm{OH}$ and $j\left(\mathrm{O}^{1} \mathrm{D}\right)$ can be estimated by removing the LIF and FR instrument

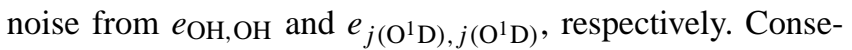
quently, the real $r^{2}$ of the observed values is determined to be 0.80 which is much better than the correlation predicted by the base model $\left(r^{2}=0.63\right)$. The fact that the current model cannot reproduce the observed high correlation between $\mathrm{OH}$ and $j\left(\mathrm{O}^{1} \mathrm{D}\right)$ seems to be a general feature, which is in line with previous results from other locations (Berresheim et al., 2003; Rohrer and Berresheim, 2006; Lu et al., 2012).

When applying the empirical model (Eq. 5) proposed by Rohrer and Berresheim (2006), a least square fit of the observed $\mathrm{OH}$ and $j\left(\mathrm{O}^{1} \mathrm{D}\right)$ yields the parameters $a=4.4 \times$ $10^{6} \mathrm{~cm}^{-3}, b=0.88$ and $c=1.4 \times 10^{6} \mathrm{~cm}^{-3}$. 
$\mathrm{OH}=a \times\left(j\left(\mathrm{O}^{1} \mathrm{D}\right) / 10^{-5} \mathrm{~s}^{-1}\right)^{b}+c$

The derived value of $b$ herein is higher than that reported for PRIDE-PRD2006 in South China (Lu et al., 2012) $(b=$ 0.68 ), but is close to the value during the POPCORN campaign in North-East Germany (Ehhalt and Rohrer, 2000) $(b=0.85)$. In principle, $b$ reflects the combined effects of all photolytic processes (e.g. $\mathrm{d}\left\{\ln \left(j\left(\mathrm{NO}_{2}\right)\right)\right\} / \mathrm{d}\left\{\ln \left(j\left(\mathrm{O}^{1} \mathrm{D}\right)\right)\right\}$, etc.). However, for the three campaigns mentioned, the sensitivity ratio of the two most important photolysis frequencies, $\mathrm{d}\left\{\ln \left(j\left(\mathrm{NO}_{2}\right)\right)\right\} / \mathrm{d}\left\{\ln \left(j\left(\mathrm{O}^{1} \mathrm{D}\right)\right)\right\}$, has essentially the same value of 0.5 , so that the difference of $b$ between Beijing and PRIDE-PRD2006 is not understood yet. A linear fit to the $\mathrm{OH}-j\left(\mathrm{O}^{1} \mathrm{D}\right)$ relationship yields a slope of $4.0 \times 10^{11} \mathrm{~cm}^{-3} \mathrm{~s}$ and an offset of $1.6 \times 10^{6} \mathrm{~cm}^{-3}$ for Beijing. This slope is essentially the same as for PRIDE-PRD2006, both lying at the upper end of values so far reported in the literature (Lu et al., 2012, and reference therein).

\section{6 $\mathrm{NO}_{\mathrm{x}}$ dependence of $\mathrm{OH}$}

Besides solar radiation, the next most important influence on $\mathrm{OH}$ is expected from $\mathrm{NO}_{\mathrm{x}}$ (Ehhalt, 1999; McKeen et al., 1997; Poppe et al., 1993; Weinstock et al., 1980). Figure 7c compares the $\mathrm{NO}_{\mathrm{x}}$ dependence of measured and modelled $\mathrm{OH}$ after normalization to the mean value of $j\left(\mathrm{O}^{1} \mathrm{D}\right)$. The functional dependence of $\mathrm{OH}_{\mathrm{Jnorm}}$ on $\mathrm{NO}_{\mathrm{x}}$ for the observed dataset shows a flat curve. This behavior does not agree with the model-predicted strong nonlinear dependence of $\mathrm{OH}$ on $\mathrm{NO}_{\mathrm{x}}$. The data at high $\mathrm{NO}_{\mathrm{x}}$ correspond to observations during morning hours. Here, the small deviation between model and observation is mainly caused by the data from 20 August. At low $\mathrm{NO}_{\mathrm{x}}$, the model underestimates the measured $\mathrm{OH}$ data significantly by a factor up to 3 around $1 \mathrm{ppb}$ of $\mathrm{NO}_{\mathrm{x}}$. The almost missing $\mathrm{NO}_{\mathrm{x}}$ dependence looks similar to the behaviour at PRD, contrasting the results obtained in much cleaner air where the theoretical dependence was confirmed by measurements (Ehhalt, 1999; Ehhalt and Rohrer, 2000; Holland et al., 2003).

\section{Discussion}

\subsection{Primary radical production in urban atmospheres}

Primary radical production during CAREBeijing2006 originated from a diversity of sources. Major contributions came from the photolysis of $\mathrm{O}_{3}$, $\mathrm{HONO}, \mathrm{HCHO}$ and dicarbonyls. The situation was similar to that reported in PRD ( $\mathrm{Lu}$ et al., 2012; Li et al., 2012; Su et al., 2008), Mexico City (Volkamer et al., 2010; Dusanter et al., 2009), and Tokyo (Kanaya et al., 2007). In other cities, radical production was often dominated by one or two of these sources. For example, photolysis of HONO was the dominant pathway ( $>50 \%$ ) in New York
City (Ren et al., 2003), so was photolysis of $\mathrm{O}_{3}(30-50 \%)$ in California (Volkamer et al., 2010), $\mathrm{O}_{3}$ and HCHO photolysis (> 50-80\%) in Milan (Alicke et al., 2002) and Nashville (Martinez et al., 2003), and photolysis of dicarbonyls plus ozonolysis of alkenes (60-90\%) in Birmingham (Emmerson et al., 2005) and London (Emmerson et al., 2007).

\section{2 $\mathrm{OH}$ model performance in different urban-influenced atmospheres}

The comparison of measured and modelled $\mathrm{HO}_{\mathrm{x}}$ for the days with prevailing wind from the south (Fig. 3, left column panels) demonstrates deficits in the current understanding of $\mathrm{OH}$ chemistry. When regionally aged air pollution was advected from the south, a strong underprediction of $\mathrm{OH}$ is found at low $\mathrm{NO}_{\mathrm{x}}$. A strong $\mathrm{OH}$ underprediction was also reported for the PRIDE-PRD2006 campaign (Hofzumahaus et al., 2009; Lu et al., 2012), where the atmospheric-chemical conditions were quite similar to that of Yufa. Both sites, Yufa and PRD, are subject to rural and urban influences. Yufa is a more urban site which is influenced by biogenic and anthropogenic emissions from surrounding regions, while the measurement site in PRD was more rural, but exposed to advected aged pollution from the megacity Guangzhou. At both field sites a mixture of anthropogenic VOCs (mainly alkenes and aromatics) and biogenic VOCs (mainly isoprene) was observed, with a high total VOC reactivity in the range of $10-30 \mathrm{~s}^{-1}$ during daytime. At slow, almost stagnant wind conditions, both field sites were exposed to aged air pollution most of the time. Another similarity is the mean diurnal variation of $\mathrm{NO}$, which showed high values in the morning (typ. 1-20 ppb) and a strong decrease to values around $0.1-0.2 \mathrm{ppb}$ in the afternoon.

A major result of the PRD study was the discovery of a significant NO dependence of the discrepancy between measured and modelled $\mathrm{OH}$ during daytime (Lu et al., 2012). The corresponding observed-to-modelled $\mathrm{OH}$ ratio is shown as open blue-square symbols in Fig. 8a as a function of NO for $j\left(\mathrm{O}^{1} \mathrm{D}\right)>0.5 \times 10^{-5} \mathrm{~s}^{-1}$. Large model-measurement discrepancies of about a factor of 5 are found at the lowend of the NO scale. Towards higher NO, the discrepany decreases and the observed-to-modelled $\mathrm{OH}$ ratio becomes unity above $1 \mathrm{ppb}$ NO. A very similar behaviour is found for the $\mathrm{OH}$ ratio at Yufa shown in Fig. 8b (open blue-square symbols). Here, the NO scale extends to even larger values according to the urban character of Yufa. Again, the largest observed-to-modelled $\mathrm{OH}$ ratios are found at the lowest $\mathrm{NO}$ values, reaching a factor of 2.6 at $0.1 \mathrm{ppb}$ NO. Like at PRD, the discrepancy disappears above $1 \mathrm{ppb}$ NO. Although the observed-to-modelled $\mathrm{OH}$ ratios for PRD and Yufa show a similar relative dependence on $\mathrm{NO}$, the discrepancies in the low NO range at Yufa are significantly smaller than at PRD. This demonstrates that other factors besides NO also influence the $\mathrm{OH}$ underprediction. 

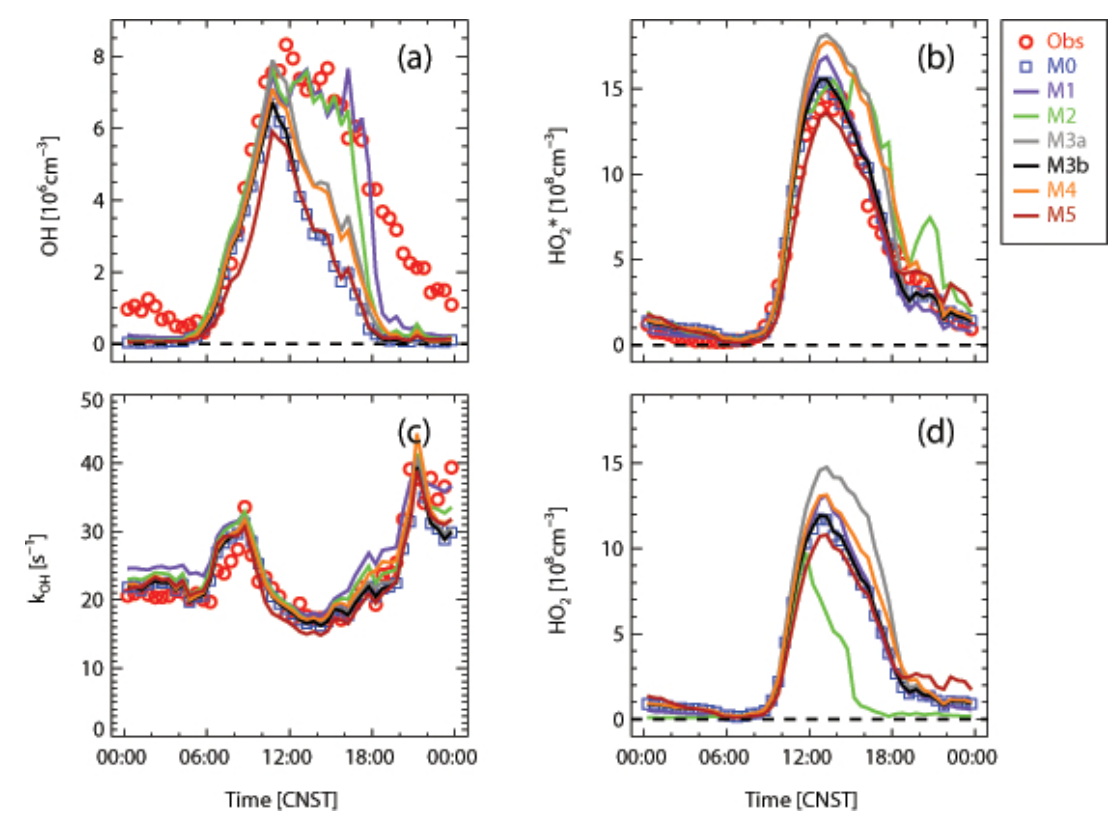

Fig. 9. Comparison of measured and calculated $\mathrm{OH}(\mathbf{a}), \mathrm{HO}_{2}^{*}(\mathbf{b}), k_{\mathrm{OH}}(\mathbf{c})$ for six different mechanistic scenarios (M0-M5, see Table 4) at southerly wind conditions. In addition, model results are compared for $\mathrm{HO}_{2}(\mathbf{d})$.

The $\mathrm{OH}$ reactivity data in Fig. 8 show that the total VOC reactivity at low NO was generally smaller at Yufa (about $16 \mathrm{~s}^{-1}$ ) compared to PRD (about $20 \mathrm{~s}^{-1}$ ). In the afternoon, the isoprene concentration was generally smaller at Yufa (about $0.8 \mathrm{ppb}$ ) compared to PRD (1.8 ppb), while anthropogenic pollutants had larger mixing ratios at Yufa (e.g. $650 \mathrm{ppb} \mathrm{CO}, 4.5 \mathrm{ppb}$ ethane, $1.8 \mathrm{ppb}$ toluene) compared to PRD (420 ppb CO, $1.5 \mathrm{ppb}$ ethane, $1.2 \mathrm{ppb}$ toluene). Another difference was the much weaker solar actinic flux at Beijing $\left(39.5^{\circ} \mathrm{N}\right.$, August) compared to the subtropical site in PRD (23.5 $\mathrm{N}$, July). The possible influence of these conditions is considered in the model tests presented below.

Other field studies which investigated the $\mathrm{OH}$ chemistry in urban environments during summertime, took place in Los Angeles (George et al., 1999), Nashville (Martinez et al., 2003), New York (Ren et al., 2003), Tokyo (Kanaya et al., 2007), London (Emmerson et al., 2007), Mexcio City (Shirley et al., 2006; Sheehy et al., 2010; Dusanter et al., 2009) and Houston (Chen et al., 2010). A common feature of these cities are large VOC reactivities (10-200 s $\mathrm{s}^{-1}$ ) and generally high NO concentrations (1-70 ppb). For some cities, the models overpredict the summertime $\mathrm{OH}$ observations. For example, an overprediction by a factor of 1.24 and up to 1.5 was found in London (Emmerson et al., 2007) and Los Angeles (George et al., 1999), respectively. In the other cities, underpredictions by up to a factor of two were reported (cf. Table 1 in Chen et al., 2010). The general agreement within a factor of two is consistent with our observations at high NO values in Yufa and PRD.
Besides PRIDE-PRD2006 and CAREBeijing2006, only one other urban field study has reported a comparison of measured $\mathrm{OH}$ with model results that extends to low NO concentrations. Kanaya et al. (2007, Fig. 9d) report a NO dependence of measured and modelled $\mathrm{OH}$ concentrations at summertime in Tokyo over a range of $0.1-20 \mathrm{ppb}$ NO. Above $1 \mathrm{ppb}$ NO, they find a reasonable model-measurement agreement, but an increasing underprediction by the model towards decreasing NO values. They find an observed-tomodelled $\mathrm{OH}$ ratio of a factor of 2 around $0.2 \mathrm{ppb} \mathrm{NO}$, which is similar to our findings (factor 2.6) in Yufa.

Missing $\mathrm{OH}$ recycling in the model has been proposed by Hofzumahaus et al. (2009) and Lu et al. (2012) as a reason for the OH discrepancy in PRD. Lu et al. (2012) discussed the similarity of the PRD results to observations in forests, where a significant underprediction of the measured $\mathrm{OH}$ has been found also (e.g. Tan et al., 2001; Lelieveld et al., 2008; Ren et al., 2008; Whalley et al., 2011). Air masses above forests are characterized by high biogenic VOC reactivities, usually dominated by some ppb of isoprene, and low concentrations of NO owing to the lack of anthropogenic emissions. Like for $\mathrm{PRD}$, missing $\mathrm{OH}$ recycling in the models was assumed to explain the unexpectedly high $\mathrm{OH}$ concentrations in forests (Tan et al., 2001; Lelieveld et al., 2008; Paulot et al., 2009; Peeters and Müller, 2010; Whalley et al., 2011). Various new mechanisms were proposed to fill the gap between modelled and measured $\mathrm{OH}$. In the following, we will test how well these mechanisms can explain the $\mathrm{OH}$ discrepancies that we found at Beijing. 


\subsection{Model tests}

A model sensitivity study was performed by implementing different $\mathrm{OH}$ recycling mechanisms in the base model, listed in Table 4. The model scenarios M1 and M2 include additional recycling of peroxy radicals with an unidentified species X (M1) or Y (M2) as proposed in the PRD study (Hofzumahaus et al., 2009; Lu et al., 2012).

$\mathrm{HO}_{2}+\mathrm{X}($ or $\mathrm{Y}) \rightarrow \mathrm{OH}$

$\mathrm{RO}_{2}+\mathrm{X} \rightarrow \mathrm{HO}_{2}$

Another scenario, M3a, incorporates the theoretical Leuven Isoprene Mechanism (LIM0) by Peeters and Müller (2010) assuming fast isomerization and decomposition of isoprene peroxy radicals (ISOP). The isomerization can proceed by intramolecular 1,5-H- or 1,6- $\mathrm{H}$-shifts and yield $\mathrm{OH}$ or $\mathrm{HO}_{2}$, respectively.

$$
\begin{aligned}
\text { ISOP } & \rightarrow 0.9 \times \mathrm{OH}+0.9 \times \mathrm{HCHO}+0.3 \\
& \times \mathrm{MACR}+0.6 \times \mathrm{MVK} \\
\mathrm{ISOP} & \rightarrow 0.9 \times \mathrm{HO}_{2}+0.6 \times \mathrm{HPALD} 1+0.3 \times \mathrm{HPALD} 2
\end{aligned}
$$

Among these two reactions, the 1,6-H-shift is predicted to be the dominating path. The resulting HPALDs (isoprene hydroperoxy aldehydes) are further assumed to undergo $\mathrm{OH}$ neutral reactions, or to produce photochemically up to three additional $\mathrm{OH}$ radicals (Peeters et al., 2009).

$\mathrm{HPALD} 1,2+\mathrm{OH} \rightarrow \mathrm{OH}$

HPALD $1,2+h v \rightarrow m \times \mathrm{OH}+\mathrm{HO}_{2}+\mathrm{OVOCs}(m \leq 3)$

Rate constants for these reactions and the yields of OVOCs (hydroxyacetone, glycolaldehyde, methylglyoxal, glyoxal, HCHO) from HPALD photolysis have been taken from Peeters and Müller (2010). The implementation into the base model (M0) is explained in detail in Lu et al. (2012). A new laboratory study confirms that the photolysis frequency of HPALDs is as fast as estimated in LIM0 (Wolfe et al., 2012), while the isomerization by the $1,6-\mathrm{H}$-shift is most likely a factor of 50 slower than theoretically predicted (Crounse et al., 2011). Therefore, an additional scenario M3b with a factor of 50 reduced reaction rate was also tested.

Scenario M4 contains the empirical Mainz Isoprene Mechanism MIM2 ${ }^{+}$(Taraborrelli et al., 2009; Lelieveld et al., 2008). MIM $2^{+}$assumes a fast production of $\mathrm{OH}$ through cross reactions of peroxy radicals with an $\mathrm{OH}$ yield of 2-4 for the conditions in Suriname (Lelieveld et al., 2008). Here, we assume

$\mathrm{ISOP}+\mathrm{HO}_{2} \rightarrow 4 \times \mathrm{OH}$

Scenario M5 uses the MCMv3.2 as a benchmark test (cf. Sect. 2.2). As will be dicussed below, we have considered two more cases for a specific period (20 August 2006) with an additional primary source of $\mathrm{OH}(\mathrm{M} 6)$ and $\mathrm{HO}_{2}$ (M7).

\subsubsection{Southerly wind days}

Model results of the scenarios M0-M5 are compared to measurements of $\mathrm{HO}_{\mathrm{x}}$ and $k_{\mathrm{OH}}$ in Fig. 9 for days with southerly wind. Like in the base case (Sect. 3.4), the results for M1-M4 were tested for uncertainties caused by unconstrained calculated OVOCs. The corresponding test runs (see Supplement, Figs. S6 and S7) yield similar results as in Fig. 9, suggesting that the conclusions of the model-measurement comparison presented below are not substantially affected by the uncertainty of the calculated OVOCs.

\section{MCMv3.2 (M5)}

The comparison of the base model with MCMv3.2 allows to inspect the impact of a higher degree of mechanistic detail on the model results. The two model runs (M0, M5) show a relatively good agreement of $\mathrm{OH}, \mathrm{HO}_{2}^{*}, \mathrm{HO}_{2}$ and $k_{\mathrm{OH}}$ during daytime, especially for the afternoon hours. The results indicate that the higher level of detail in the chemistry of MCMv3.2 compared to RACM-MIM-GK does not have a significant influence on the major discrepancies between observed and modelled $\mathrm{OH}$ in the afternoon. RACM-MIM-GK is therefore suitable as a base mechanism for the model tests, consistent with the findings from the PRD study ( $\mathrm{Lu}$ et al., 2012). A slight difference of $18 \%$ between $\mathrm{OH}$ calculated by $\mathrm{M} 0$ and M5 can be noted during the morning hours, resulting from a $30 \%$ difference of the rate constants $k_{\mathrm{OH}+\mathrm{NO}_{2}}$ implemented in MCMv3.2 and RACM-MIM-GK. In the morning at high $\mathrm{NO}_{\mathrm{x}}, \mathrm{OH}$ losses are dominated by the reaction with $\mathrm{NO}_{2}$ (Reaction R10) explaining the large sensitivity to $k_{\mathrm{OH}+\mathrm{NO}_{2}}$. The rate constant implemented in RACM-MIMGK is almost identical to the latest experimental results reported by Mollner et al. (2010). We find that this implementation in RACM-MIM-GK in comparison to that of MCMv3.2 shows a better agreement with observed $\mathrm{OH}$ concentrations in the high $\mathrm{NO}_{\mathrm{x}}$ regime.

\section{Additional recycling by X, Y (M1, M2)}

In scenarios M1 and M2, two different kinds of generic radical recycling pathways are embedded in the model. Good agreement between observed and modelled $\mathrm{OH}$ concentrations could be achieved during daytime by numerical fitting of the generic species $\mathrm{X}$ and $\mathrm{Y}$. The inclusion of the reactions with $\mathrm{X}$ or $\mathrm{Y}$ does not change the good model-measurement agreement of $\mathrm{HO}_{2}^{*}$ and $k_{\mathrm{OH}}$ values within experimental uncertainty, compared to the base case. The cause for the robust calculation of $\mathrm{HO}_{2}^{*}$ is diverse. In M1, the added recycling reactions of $\mathrm{HO}_{2}$ and $\mathrm{RO}_{2}$ change the production and destruction rates of $\mathrm{HO}_{2}$ by roughly the same amount, so that the two effects cancel out. In M2, the reduction of $\mathrm{HO}_{2}$ is compensated by the enhancement of $\mathrm{RO}_{2}$ so that the resulting $\mathrm{HO}_{2}^{*}$ is still conserved. With respect to $k_{\mathrm{OH}}$, the total 
reactivity of hydrocarbons, $\mathrm{NO}_{\mathrm{x}}$ and $\mathrm{CO}$ are fixed to measurements and only the contribution from modelled OVOCs may be influenced by mechanistic model changes. Lou et al. (2010) showed for a similar case (PRD) that the OVOC reactivity is not very sensitive to changes in daytime $\mathrm{OH}$, because the production and a major part of the destruction of OVOCs is driven by $\mathrm{OH}$, compensating the influence of $\mathrm{OH}$ in the model.

In M1 and M2, the derived diurnal profiles of $\mathrm{X}$ and $\mathrm{Y}$ show some variability with maximum concentrations appearing at late afternoon hours $(\approx 18: 00 \mathrm{CNST})$ while minimum concentrations appeared in the morning hours (see Fig. S5). This correlates with the diurnal behavior of the required $\mathrm{OH}$ source (see Fig. 3a). The averaged concentration of $X$ is equivalent to about $0.4 \mathrm{ppb}$ NO during daytime, while the required $\mathrm{Y}$ concentration is up to $10 \mathrm{ppb}$ in the late afternoon. Compared to PRIDE-PRD2006, the required concentration of $\mathrm{X}$ is about $50 \%$ smaller, while the modelled $\mathrm{HO}_{2}$ is about the same. Thus, the missing $\mathrm{OH}$ source at Yufa has about half of the source strength required at PRD. The calculated concentration of $\mathrm{Y}$ in this study is close to that of PRD, but the modelled $\mathrm{HO}_{2}$ concentration is much smaller in the afternoon. Again, the missing $\mathrm{OH}$ source is about half of the value needed in PRD.

We find that the mechanism M1 and M2 provides a description of measured $\mathrm{OH}$ only during daylight. After sunset, the reactions with $\mathrm{X}$ or $\mathrm{Y}$ are not sufficient to explain the observed $\mathrm{OH}$ levels. Besides extra recycling, an additional primary $\mathrm{RO}_{\mathrm{x}}$ radical source $\left(\leq 1 \mathrm{ppbh}^{-1}\right)$ is also needed at night. Details of this analysis will be given in a separate publication.

As discusssed by Lu et al. (2012), the nature of the unknown species $\mathrm{X}$ or $\mathrm{Y}$ has not been identified yet. Taking into accout the common observation that unexplained high daytime $\mathrm{OH}$ is found in areas with high VOC reactivities, i.e. in forests (e.g. Tan et al., 2001; Lelieveld et al., 2008; Ren et al., 2008; Whalley et al., 2011), PRD (Lu et al., 2012), Tokyo (Kanaya et al., 2007), and Beijing (this work), it is probable that the missing mechanism of $\mathrm{OH}$ recycling is linked to degradation products of biogenic and/or anthropogenic VOCs. In that sense, Reactions (R14a) and (R14b) must be considered generic place holders for more detailed mechanisms.

\section{OH recycling from ISOP $(\mathrm{M3}, \mathrm{M4})$}

The observation of missing $\mathrm{OH}$ recycling in forests has led to the hypothesis that isoprene peroxy radicals (ISOP) may reproduce $\mathrm{OH}$ efficiently in the absence of $\mathrm{NO}$ (Peeters and Müller, 2010; Lelieveld et al., 2008). This possibility is represented by the LIM0 and MIM2+ ${ }^{+}$schemes, respectively, which are tested in scenarios M3a and M4. Both mechanisms produce more $\mathrm{OH}$ than is consumed leading to radical amplification. Both scenarios yield very similar diurnal $\mathrm{OH}$ profiles (Fig. 9). In the morning, the additional isoprene peroxy radical chemistry given by Reactions (R16)-(R18) and (R19) has almost no influence on $\mathrm{OH}$ owing to the dominant role of Reaction (R6) in the presence of high NO. In the afternoon, at a reduced NO level of about $100 \mathrm{ppt}$, the new isoprene chemical schemes become important and enhance the $\mathrm{OH}$ concentration by about a factor of 1.6. At daytime $\left(j\left(\mathrm{O}^{1} \mathrm{D}\right)>0.5 \times 10^{-5} \mathrm{~s}^{-1}\right)$ a discrepancy of a factor of 1.6 remains between observed and modelled $\mathrm{OH}$, much of which may be explained by a conservatively estimated combined measurement-and-model error of $45 \%$ (cf. Fig. 8). LIM0 and $\mathrm{MIM}^{+}$generate also systematically larger $\mathrm{HO}_{2}$ and $\mathrm{HO}_{2}^{*}$ concentrations than $\mathrm{M} 0$. The resulting $\mathrm{HO}_{2}^{*}$ values still agree with the measured values within their errors. The modelled $k_{\mathrm{OH}}$ in scenarios M3a and M4 essentially agree with the measured values as well as in the previous scenarios M0$\mathrm{M} 2$. Thus, the isoprene-based $\mathrm{OH}$ recycling mechanisms by Peeters and Müller (2010) and Lelieveld et al. (2008) have the potential to explain the missing daytime source of $\mathrm{OH}$ at Yufa if conservative error estimates are taken into account. This outcome differs from the results at PRD, where a significant discrepancy of a factor of two remained between measured and modelled $\mathrm{OH}$ when the LIM or MIM2 ${ }^{+}$mechanisms were applied (cf. Fig. 8 and Lu et al., 2012).

The capability of LIM0 to amplify OH relies on the efficient production of HPALDs (Reaction R16) and their subsequent photolysis yielding $\mathrm{OH}$ radicals (Reaction R18). If this mechanism is correct, an improved correlation between modelled $\mathrm{OH}$ and $\mathrm{j}\left(\mathrm{O}^{1} \mathrm{D}\right)$ would be expected for LIM0 compared to the base case. No significant difference in the correlation coefficients is found between $\mathrm{M} 0\left(r^{2}=0.63\right)$ and $\mathrm{M} 3 \mathrm{a}$ $\left(r^{2}=0.64\right)$ suggesting that the photolysis of HPALDs was probably not the major missing $\mathrm{OH}$ source. Based on a laboratory study of stable isoprene oxidation products, Crounse et al. (2011) concluded that the isomerization rate of ISOP in the LIM mechanism must be about 50 times slower than predicted by the ab-initio calculations of Peeters and Müller (2010). Using the reduced rate in our model (M3b), no significant change of the modelled $\mathrm{OH}, \mathrm{HO}_{2}$ and $\mathrm{RO}_{2}$ concentrations is found compared to the base case. Thus, if the conclusion by Crounse et al. (2011) is correct, the isomerization of isoprene peroxy radicals as proposed in the LIM mechanism would not be able to contribute significantly to the explanation of the observed $\mathrm{OH}$ discrepancy at Yufa.

\section{Further discussion}

Studies of ambient $\mathrm{HO}_{\mathrm{x}}$ during the field campaign HOxComp2005 in Jülich have shown relatively good agreement (within $30 \%$ ) between modelled and measured $\mathrm{OH}$ (Elshorbany et al., 2012; Kanaya et al., 2012). Interestingly, agreement was found both for high and low NO concentrations, contrasting the PRD and Yufa results where significant $\mathrm{OH}$ discrepancies were found at similar isoprene 
concentrations at low NO. Although $\mathrm{OH}$ was well matched in the HOxComp studies, $\mathrm{HO}_{2}$ was overpredicted by the models by up to a factor of two at low $\mathrm{NO}_{\mathrm{x}}$ indicating a major deficit in the model description of $\mathrm{HO}_{\mathrm{x}}$ recyling. An overpredicted $\mathrm{HO}_{2}$ concentration implies an overestimation of the $\mathrm{HO}_{2}$ to $\mathrm{OH}$ recycling rate. This and the good model-measurement agreement for $\mathrm{OH}$ means that a real $\mathrm{OH}$ source is missing in the model. In fact, the direct comparison of experimentally determined $\mathrm{OH}$ loss and production rates showed evidence of a missing $\mathrm{OH}$ source $\left(2-5 \mathrm{ppb} \mathrm{h}^{-1}\right)$ specifically at low NO concentrations (Elshorbany et al., 2012), though much smaller than the average missing $\mathrm{OH}$ source at PRD $\left(25 \mathrm{ppb} \mathrm{h}^{-1}\right)$ and Yufa $\left(11 \mathrm{ppbh}^{-1}\right)$. The possible reason for the different required source strengths could be the much shorter photochemical aging of isoprene at HOxComp (Kanaya et al., 2012), or the presence of much higher amounts of other, mostly anthropogenic VOCs at PRD and Yufa. In addition, the nighttime measurements at HOxComp2005 were much lower $\left(<1 \times 10^{6} \mathrm{~cm}^{-3}\right)$ and in reasonably agreement with the model, providing no potential explanation for the high nighttime measurement values at Yufa.

The uncertainty of the LIM mechanism and the fact that even the fast isomerization rate of ISOP would not be sufficient to resolve the complete $\mathrm{OH}$ discrepancy at $\mathrm{PRD}$, gives room for speculations about recycling mechanisms linked to other VOCs. According to previous theoretical (Da Silva et al., 2010) and chamber (Bloss et al., 2005) studies, peroxy radicals from 1,3-butadiene and toluene have been postulated to produce $\mathrm{OH}$ in the absence of NO. This hypothesis is further supported in laboratory experiments by Birdsall and Elrod (2011) who conclude that bicyclic peroxy radicals from toluene may react with $\mathrm{HO}_{2}$ and form $\mathrm{OH}$. However, specific rate constants are not yet known. In our case, 1,3-butadiene and toluene contribute only $0.6 \%$ and $1.6 \%$ of the total $\mathrm{OH}$ reactivity, while isoprene has a share of $43.5 \%$ in the afternoon. Thus the impact of 1,3-butadiene and toluene alone would be likely very small. In any case, further laboratory studies of the chemical degradation of alkenes and aromatics at low NO will be needed to improve the understanding of $\mathrm{HO}_{\mathrm{x}}$ in urban influenced atmospheres.

Aerosol concentrations in Yufa were high and are of potential importance for the budget of $\mathrm{HO}_{\mathrm{x}}$ and the missing $\mathrm{OH}$ recycling process. The average aerosol surface-area density at daytime was about $1400 \mu \mathrm{m}^{2} \mathrm{~cm}^{-3}$ (A. Nowak, personal communication, 2012) which is very similar to the values observed in PRD (Lu et al., 2012). Accordingly, as reported by $\mathrm{Lu}$ et al. (2012), a considerable $\mathrm{HO}_{2}$ reduction in the order of $50 \%$ can be expected by heterogeneous $\mathrm{HO}_{2}$ loss, if an uptake coefficient of 0.5 is assumed. The aerosols at Yufa were mainly composed of soot and organic material (Garland et al., 2009), for which uptake coefficients of less than 0.1 are likely (Thornton and Abbatt, 2005; Bedjanian et al., 2005; Taketani et al., 2009, 2010). Based on the latter values, the $\mathrm{HO}_{2}$ reduction by aerosols is probably smaller than $20 \%$. A hypothetical $\mathrm{HO}_{2}$ to $\mathrm{OH}$ recycling process aided by a heterogeneous aeorosol process appears therefore to be an unlikely explanation for the missing $\mathrm{OH}$ source.

A potential explanation for the $\mathrm{OH}$ discrepancy would be an interference in the $\mathrm{OH}$ measurements caused by VOC oxidation products. For example, Mao et al. (2012) discovered a factor-of-two $\mathrm{OH}$ interference for the Pennstate LIF system when the traditional wavelength modulation technique was used for $\mathrm{OH}$ measurements in a Ponderosa pine plantation. We have tested our LIF instrument for possible VOC-related interferences by an $\mathrm{OH}$ intercomparison between LIF and laser differential absorption spectroscopy (DOAS) (Fuchs et al., 2012). The test was performed for those VOCs (isoprene, MVK, MACR, $t$-butene, benzene, toluene, $p$-xylene, mesitylene) that played a major role in PRD and Yufa. The comparison was performed in the atmosphere simulation chamber SAPHIR in Jülich at VOC reactivities up to $30 \mathrm{~s}^{-1}$ and low NO concentrations $(0.1-0.3 \mathrm{ppb})$ in the presence of $\mathrm{OH}$ and ozone. For most of the VOCs (including isoprene), no measurement artefact was discovered. Only in case of MVK (20 ppb) and toluene ( $80 \mathrm{ppb})$, a discrepancy with a large uncertainty was found, with LIF measurements being higher by $30-40 \%$ than the DOAS values. Since the corresponding VOC concentrations were much smaller in the field experiments, the supposed artefacts are not a likely explanation for the high $\mathrm{OH}$ values observed in Yufa or PRD.

\subsubsection{Special case: 20 August}

The comparison of measured and modelled $\mathrm{HO}_{\mathrm{x}}$ data at Yufa for the days with northerly wind (Fig. 3d, 20 August) yields an $\mathrm{OH}$ underprediction by up to a factor of four in the morning at high $\mathrm{NO}_{\mathrm{x}}$. The underpredicted $\mathrm{OH}$ is partly related to the overpredicted $\mathrm{OH}$ reactivity (Fig. 3h). On this day, freshly emitted pollutants from Beijing City were transported by a fast wind $\left(\approx 6 \mathrm{~m} \mathrm{~s}^{-1}\right)$ to the field site. Unlike for the days with southerly winds (cf. Sects. 3.1 and 3.4), emitted VOCs were probably less photochemically aged on their arrival at Yufa than implicitly assumed by the model, which calculates quasi steady-state concentrations of the products. Thus, the modelled contribution of oxidation products to $k_{\mathrm{OH}}$ may be overestimated. To correct for this bias, we artificially assumed dilution for the model calculated species to match the observed $k_{\mathrm{OH}}$. A dilution lifetime of $8 \mathrm{~h}$ was found suitable to mimic a shorter time scale between emission and observation (Fig. 10). The new model run, M0+ $\tau_{8 \mathrm{~h}}$ reproduces the observed $k_{\mathrm{OH}}$. The improved match for $k_{\mathrm{OH}}$ is the result of a reduction of calculated OVOCs, since the concentrations of $\mathrm{NO}_{\mathrm{x}}, \mathrm{CO}$ and VOCs are constrained by measurements. The chemical species contributing mostly to the OVOC reduction are HCHO (53\%), ALD (13\%), MGLY $(12 \%)$ and MACR+MVK+CAR4 $(11 \%)$. Due to the relative small sensitivity of $\mathrm{OH}$ and $\mathrm{HO}_{2}^{*}$ to variations of OVOCs (Sect. 3.4), $\mathrm{OH}$ and $\mathrm{HO}_{2}^{*}$ concentrations are still underestimated before 14:00 CNST (Fig. 10). The underprediction of $\mathrm{OH}$ can be seen more clearly as a function of daytime and NO 

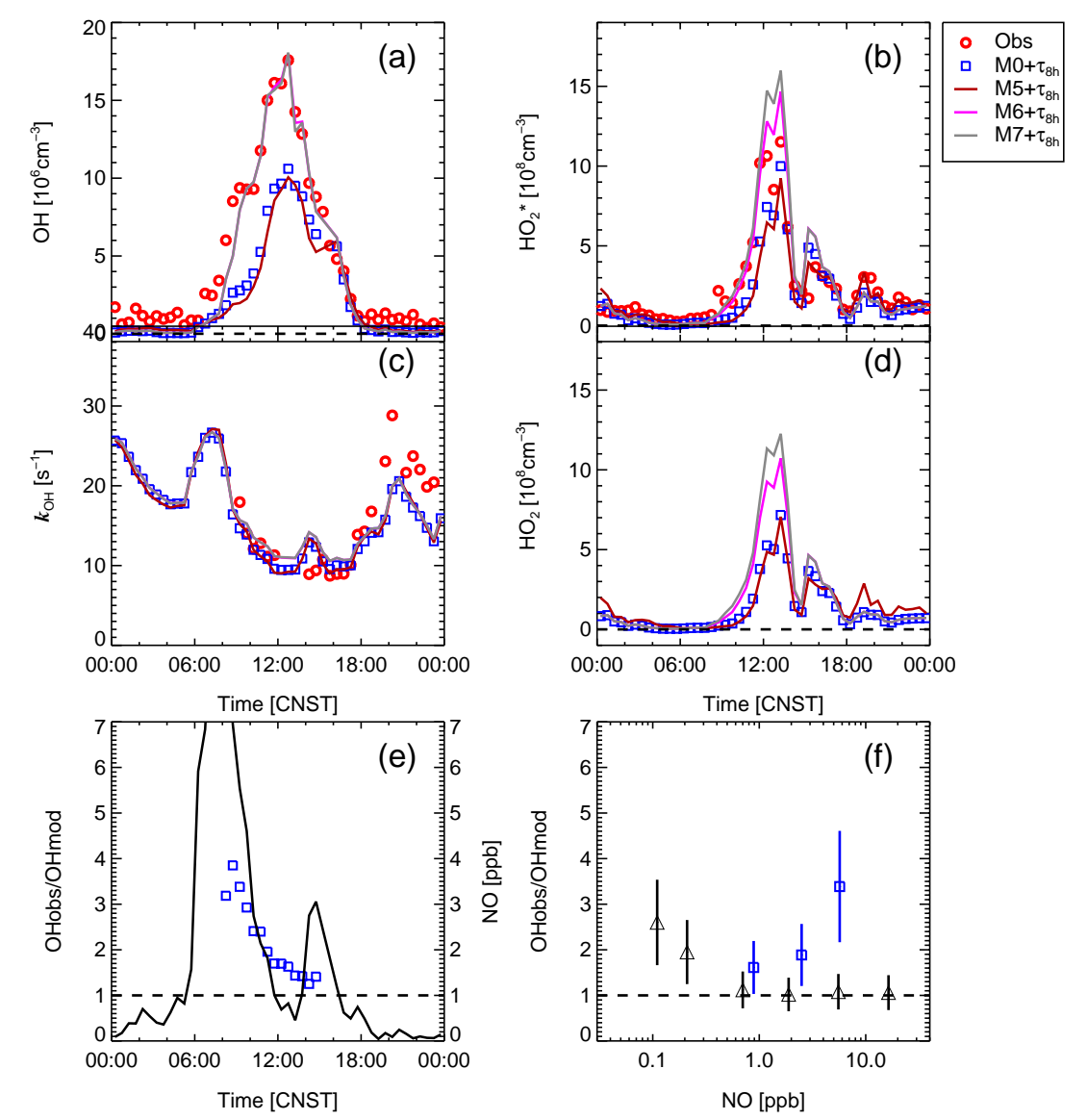

Fig. 10. Comparison of measured and calculated $\mathrm{OH}(\mathbf{a}), \mathrm{HO}_{2}^{*}(\mathbf{b}), k_{\mathrm{OH}}(\mathbf{c})$ for four different mechanistic scenarios $\left(\mathrm{M} 0+\tau_{8 \mathrm{~h}}, \mathrm{M} 5+\tau_{8 \mathrm{~h}}\right.$, $\mathrm{M} 6+\tau_{8 \mathrm{~h}}$, and $\mathrm{M} 7+\tau_{8 \mathrm{~h}}$ ) on 20 August. Model results for $\mathrm{HO}_{2}(\mathbf{d})$ are also shown. The diurnal variation and NO dependence of the observedto-modelled $\mathrm{OH}$ ratio $\left(\mathrm{OH}_{\mathrm{obs}} / \mathrm{OH}_{\text {mod }}\right)$ for $\mathrm{M} 0+\tau_{8 \mathrm{~h}}$ are shown as blue squares in (e) and (f). The $\mathrm{NO}$ dependence of $\mathrm{OH}_{\mathrm{obs}} / \mathrm{OH}_{\mathrm{mod}}$ for southerly wind days is shown as reference in (f) by open triangles. Vertical error bars denote combined $1 \sigma$ accuracies of the modelled (M0) and observed $\mathrm{OH}$ concentrations.

plotted in blue symbols in Figs. 10e and 10f, respectively. The observed-to-modelled $\mathrm{OH}$ ratio $\left(\mathrm{OH}_{\mathrm{obs}} / \mathrm{OH}_{\text {mod }}\right)$ shows an increasing trend with $\mathrm{NO}$ opposed to the behaviour of $\mathrm{OH}$ on days with southerly wind. On 20 August, measured and modelled $\mathrm{OH}$ agree at concentrations around $1 \mathrm{ppb}$, while a significant discrepancy by a factor about 3.5 appears at $\sim 5 \mathrm{ppb}$. Similar results are obtained in model run M5+ $\tau_{8 \mathrm{~h}}$ which is compared to $\mathrm{M} 0+\tau_{8 \mathrm{~h}}$ in Fig. 10a.

As a further test, additional primary production for $\mathrm{OH}$ $\left(\mathrm{M} 6+\tau_{8 \mathrm{~h}}\right)$ or $\mathrm{HO}_{2}\left(\mathrm{M} 7+\tau_{8 \mathrm{~h}}\right)$ is introduced in the model. The required production rates denoted as $Q(\mathrm{OH})$ and $Q\left(\mathrm{HO}_{2}\right)$, respectively, are optimized to match the $\mathrm{HO}_{\mathrm{x}}$ observations. In case of model run M6+ $\tau_{8} \mathrm{~h}$, very good agreement of modelled and measured $\mathrm{OH}$ is obtained when an average $\mathrm{OH}$ source of $3.6 \mathrm{ppbh}^{-1}$ is assumed for 08:00-14:00 (Fig. 10a). Essentially the same result is obtained when an average $\mathrm{HO}_{2}$ source of $4 \mathrm{ppbh}^{-1}$ is used for 08:00-14:00. Also in case of $\mathrm{HO}_{2}^{*}$, both scenarios yield practically the same diurnal profile, which is in better agreement with the observation than the base case (Fig. 10b). The good model-measurement agreement of $k_{\mathrm{OH}}$ in scenario $\mathrm{M} 0+\tau_{8 \mathrm{~h}}$ is not changed by the additional sources of $\mathrm{OH}$ or $\mathrm{HO}_{2}$ (Fig. 10c). Apparently, the addition of a source of $\mathrm{OH}$ or $\mathrm{HO}_{2}$ has almost the same effect on both $\mathrm{HO}_{\mathrm{x}}$ species, which is a result of fast interconversion between $\mathrm{OH}$ and $\mathrm{HO}_{2}$. It can be concluded that a primary $\mathrm{HO}_{\mathrm{x}}$ source is missing, but it remains an open question whether it is a source of $\mathrm{OH}$ or $\mathrm{HO}_{2}$. The required radical sources $Q(\mathrm{OH})$ and $Q\left(\mathrm{HO}_{2}\right)$ show no dependence on $\mathrm{NO}_{\mathrm{x}}$. Both of them show a similar diurnal variation with a broad maximum during 09:00-13:00. Similar considerations of an unknown $\mathrm{HO}_{\mathrm{x}}$ source for high $\mathrm{NO}_{\mathrm{x}}$ conditions were reported for other urban plumes (Martinez et al., 2003; Ren et al., 2003; Kanaya et al., 2007; Sheehy et al., 2010; Dusanter et al., 2009). However, except for the two Mexico City campaigns (Sheehy et al., 2010; Dusanter et al., 2009), the missing $\mathrm{HO}_{\mathrm{x}}$ source in previous campaigns were mainly deduced from the underestimation of observed $\mathrm{HO}_{2}$ concentrations. Part of this underestimation might be caused by a recently discovered measurement interference resulting from a partially conversion of $\mathrm{RO}_{2}$ to $\mathrm{HO}_{2}$ in LIF instruments 
(Fuchs et al., 2011). The contribution of such an artefact is instrument-specific and, due to lack of quantification, uncertain for the reported field campaigns.

Sensitivity model runs including additional $\mathrm{OH}$ recycling mechanisms (M1-M4) have also been applied to 20 August, including the additional removal process with a lifetime of $8 \mathrm{~h}$. As expected, none of the recycling mechanisms is able to explain the observed $\mathrm{OH}$ concentrations in the morning. The changes of modelled $\mathrm{OH}$ are marginal, because the conversion of peroxy radicals to $\mathrm{OH}$ is much slower than the reaction with $\mathrm{NO}$ at the high $\mathrm{NO}_{\mathrm{x}}$ conditions on 20 August.

\section{Summary and conclusions}

Measurements of ambient $\mathrm{HO}_{\mathrm{x}}$ concentrations and total $\mathrm{OH}$ reactivity were performed by an LIF instrument at a suburban site (Yufa) in the south of Beijing City as part of the comprehensive field campaign CAREBeijing2006 in summer 2006. Observed daily maxima of $\mathrm{OH}$ and $\mathrm{HO}_{2}^{*}$ were in the range of (4-17) $\times 10^{6} \mathrm{~cm}^{-3}$ and $(2-24) \times 10^{8} \mathrm{~cm}^{-3}$, respectively. During daytime, $\mathrm{OH}$ reactivities were generally high (10-30 $\mathrm{s}^{-1}$ ) mainly contributed by VOCs and their oxidation products. Together with simultaneously measured trace gas concentrations and photolysis frequencies, a suitable dataset was collected to characterize and examine the capability of established chemical mechanisms (RACM-MIMGK and MCMv3.2) to reproduce the observed $\mathrm{HO}_{\mathrm{x}}$ concentration levels in Beijing.

For most of the days, local air chemistry was influenced by aged air masses that were advected by a slow, almost stagnant wind from the South. For these conditions, the production and destruction rates of $\mathrm{OH}$, calculated from measurements, were found to be balanced in the morning at high $\mathrm{NO}_{\mathrm{x}}$. In the afternoon at low $\mathrm{NO}_{\mathrm{x}}$ conditions, a missing $\mathrm{OH}$ source (10-20 $\mathrm{ppb} \mathrm{h}^{-1}$ ) was identified. The results from the $\mathrm{OH}$ budget analysis are consistent with a comparison between the observed $\mathrm{HO}_{\mathrm{x}}$ concentrations and results from a base model (RACM-MIM-GK). Observed OH concentrations can be reproduced by the model reasonably well during morning hours, while they are strongly underestimated in the afternoon. The observed-to-modelled $\mathrm{OH}$ ratio is found to be NO dependent. It reaches a value of 2.6 at $0.1 \mathrm{ppb} \mathrm{NO}$ and becomes unity at $\mathrm{NO}$ values above $1 \mathrm{ppb} \mathrm{NO}$. On the other hand, the observed $\mathrm{HO}_{2}^{*}$ concentrations and $k_{\mathrm{OH}}$ are well captured by the model. The model results by RACMMIM-GK are essentially confirmed by MCMv3.2 showing that the model-measurement discrepancies for $\mathrm{OH}$ are not caused by the lumped representation of organic species in the less detailed model.

After introducing an additional, generic recycling process $\mathrm{HO}_{2} \rightarrow \mathrm{OH}$, the model is able to reproduce simultaneously the observed $\mathrm{OH}, \mathrm{HO}_{2}^{*}$ and $k_{\mathrm{OH}}$ values. About half of the additional recycling rate is needed compared to the study in PRD (Lu et al., 2012), where a similar NO dependent $\mathrm{OH}$ discrepancy was found at high VOC reactivities. When recycling of $\mathrm{OH}$ from isoprene peroxy radicals as proposed by Lelieveld et al. (2008) and Peeters and Müller (2010) is implemented, much of the $\mathrm{OH}$ discrepancy at Yufa is removed, but a $40 \%$ underestimation still persists at low NO which can be explained by a conservative estimate of the model and measurement errors. However, there are still large uncertainties concerning the efficiency of $\mathrm{OH}$ recycling from isoprene peroxy radicals (e.g. Crounse et al., 2011). This and the fact that the isoprene mechanism could not explain the large discrepancy at PRD indicate need for additional laboratory studies of the oxidation chemistry of isoprene, and possibly alkenes and aromatics at low NO conditions.

For a special case, 20 August, when the Beijing city plume was enountered, an additional primary $\mathrm{HO}_{\mathrm{x}}$ source on average of about $4 \mathrm{pph}^{-1}$ and an additional dilution process with $8 \mathrm{~h}$ lifetime were required to reproduce the observed $\mathrm{HO}_{\mathrm{x}}$ and $k_{\mathrm{OH}}$ at high $\mathrm{NO}_{\mathrm{x}}$ conditions in the morning. Similar considerations of an unknown $\mathrm{HO}_{\mathrm{x}}$ source for high $\mathrm{NO}_{\mathrm{x}}$ conditions were reported for other urban plumes.

At CAREBeijing2006, the primary production of $\mathrm{RO}_{\mathrm{X}}$ radicals was generally large (approximately $7 \mathrm{ppbh}^{-1}$ ) and dominated by photolysis of $\mathrm{O}_{3}, \mathrm{HONO}, \mathrm{HCHO}$ and dicarbonyls. Half of the production rate was determined by observed parameters $\left(\mathrm{O}_{3}, \mathrm{HONO}\right)$ while the other half was contributed by calculated species (OVOCs). A similar situation applies to the radical conversion of $\mathrm{OH}$ to $\mathrm{HO}_{2}$ and $\mathrm{RO}_{2}$. This highlights the importance of OVOCs for understanding the $\mathrm{HO}_{\mathrm{x}}$ radical budgets and emphasizes the need for direct measurements of oxygenated products such as $\mathrm{HCHO}$, dicarbonyls, MACR, MVK and potentially HPALD in future field campaigns and laboratory studies.

\section{Supplementary material related to this article is available online at: http://www.atmos-chem-phys.net/13/ 1057/2013/acp-13-1057-2013-supplement.pdf.}

Acknowledgements. This work was supported by National Natural Science Foundation of China (Major Program: 21190052 and Innovative Research Group: 41121004), the Strategic Priority Research Program of the Chinese Academy of Sciences (grant no. XDB05010500), the Ministry of Science and Technology of China (no. 2002CB410801), and EU project PEGASOS (grant no. 265307). The authors would like to thank the CAREBeijing2006 science team, especially S. Guo, X. H. Wang, N. Takegawa for technical help and support at the field site, A. Nowak for providing aerosol surface-area density data, and $\mathrm{X}$. Liu for providing measured LIDAR data of the atmospheric boundary layer height.

The service charges for this open access publication have been covered by a Research Centre of the Helmholtz Association.

Edited by: D. Parrish 


\section{References}

Achtert, P., Birmili, W., Nowak, A., Wehner, B., Wiedensohler, A., Takegawa, N., Kondo, Y., Miyazaki, Y., Hu, M., and Zhu, T.: Hygroscopic growth of tropospheric particle number size distributions over the North China Plain, J. Geophys. Res., 114, D00G07, doi:10.1029/2008JD010921, 2009.

Alicke, B., Platt, U., and Stutz, J.: Impact of nitrous acid photolysis on the total hydroxyl radical budget during the Limitation of Oxidant Production/Pianura Padana Produzione di Ozono study in Milan, J. Geophys. Res., 107, 8196, doi:10.1029/2000JD000075, 2002

Amedro, D., Parker, A. E., Schoemaecker, C., and Fittschen, C.: Direct observation of $\mathrm{OH}$ radicals after $565 \mathrm{~nm}$ multi-photon excitation of $\mathrm{NO}_{2}$ in the presence of $\mathrm{H}_{2} \mathrm{O}$, Chem. Phys. Lett., 513, 12-16, doi:10.1016/j.cplett.2011.07.062, 2011.

Berresheim, H., Plass-Dülmer, C., Elste, T., Mihalopoulos, N., and Rohrer, F.: $\mathrm{OH}$ in the coastal boundary layer of Crete during MINOS: Measurements and relationship with ozone photolysis, Atmos. Chem. Phys., 3, 639-649, doi:10.5194/acp-3-639-2003, 2003

Birdsall, A. W. and Elrod, M. J.: Comprehensive NO-Dependent Study of the Products of the Oxidation of Atmospherically Relevant Aromatic Compounds, J. Phys. Chem., 115, 5397-5407, 2011

Bloss, C., Wagner, V., Jenkin, M. E., Volkamer, R., Bloss, W. J., Lee, J. D., Heard, D. E., Wirtz, K., Martin-Reviejo, M., Rea, G., Wenger, J. C., and Pilling, M. J.: Development of a detailed chemical mechanism (MCMv3.1) for the atmospheric oxidation of aromatic hydrocarbons, Atmos. Chem. Phys., 5, 641-664, doi:10.5194/acp-5-641-2005, 2005.

Bohn, B., Corlett, G. K., Gillmann, M., Sanghavi, S., Stange, G., Tensing, E., Vrekoussis, M., Bloss, W. J., Clapp, L. J., Kortner, M., Dorn, H.-P., Monks, P. S., Platt, U., Plass-Dülmer, C., Mihalopoulos, N., Heard, D. E., Clemitshaw, K. C., Meixner, F. X., Prevot, A. S. H., and Schmitt, R.: Photolysis frequency measurement techniques: results of a comparison within the ACCENT project, Atmos. Chem. Phys., 8, 5373-5391, doi:10.5194/acp-85373-2008, 2008.

Brauers, T., Hausmann, M., Bister, A., Kraus, A., and Dorn, H.P.: $\mathrm{OH}$ radicals in the boundary layer of the Atlantic Ocean 1. Measurements by long-path absorption spectroscopy, J. Geophys. Res., 106, 7399-7414, 2001.

Butler, T. M., Taraborrelli, D., Brühl, C., Fischer, H., Harder, H., Martinez, M., Williams, J., Lawrence, M. G., and Lelieveld, J.: Improved simulation of isoprene oxidation chemistry with the ECHAM5/MESSy chemistry-climate model: lessons from the GABRIEL airborne field campaign, Atmos. Chem. Phys., 8, 4529-4546, doi:10.5194/acp-8-4529-2008, 2008.

Carr, S., Heard, D. E., and Blitz, M. A.: Comment on "Atmospheric hydroxyl radical production from electronically excited $\mathrm{NO}_{2}$ and $\mathrm{H}_{2} \mathrm{O}$ ", Science, 324, 336-336, doi:10.1126/science.1166669, 2009

Chan, C. K. and Yao, X.: Air pollution in mega cities in China, Atmos. Environ., 42, 1-42, 2008.

Chen, S., Ren, X., Mao, J., Chen, Z., Brune, W. H., Lefer, B., Rappenglück, B., Flynn, J., Olson, J., and Crawford, J. H.: A comparison of chemical mechanisms based on TRAMP-2006 field data, Atmos. Environ., 44, 4116-4125, 2010.
Cheng, Y. F., Berghof, M., Garland, R. M., Wiedensohler, A., Wehner, B., Muller, T., Su, H., Zhang, Y. H., Achtert, P., Nowak, A., Poschl, U., Zhu, T., Hu, M., and Zeng, L. M.: Influence of soot mixing state on aerosol light absorption and single scattering albedo during air mass aging at a polluted regional site in northeastern China, J. Geophys. Res., 114, D00G10, doi:10.1029/2008JD010883, 2009.

Crounse, J. D., Paulot, F., Kjaergaard, H. G., and Wennberg, P. O.: Peroxy radical isomerization in the oxidation of isoprene, Phys. Chem. Chem. Phys., 13, 13607-13613, doi:10.1039/c1cp21330j, 2011.

Da Silva, G., Graham, C., and Wang, Z. F.: Unimolecular betaHydroxyperoxy Radical Decomposition with $\mathrm{OH}$ Recycling in the Photochemical Oxidation of Isoprene, Environ. Sci. Technol., 44, 250-256, doi:10.1021/es900924d, 2010.

Dillon, T. J. and Crowley, J. N.: Direct detection of $\mathrm{OH}$ formation in the reactions of $\mathrm{HO}_{2}$ with $\mathrm{CH}_{3} \mathrm{C}(\mathrm{O}) \mathrm{O}_{2}$ and other substituted peroxy radicals, Atmos. Chem. Phys., 8, 4877-4889, doi:10.5194/acp-8-4877-2008, 2008.

Dodge, M. C.: Chemical oxidant mechanisms for air quality modeling: critical review, Atmos. Environ., 34, 2103-2130, 2000.

Dunlea, E. J., Herndon, S. C., Nelson, D. D., Volkamer, R. M., San Martini, F., Sheehy, P. M., Zahniser, M. S., Shorter, J. H., Wormhoudt, J. C., Lamb, B. K., Allwine, E. J., Gaffney, J. S., Marley, N. A., Grutter, M., Marquez, C., Blanco, S., Cardenas, B., Retama, A., Ramos Villegas, C. R., Kolb, C. E., Molina, L. T. and Molina, M. J.: Evaluation of nitrogen dioxide chemiluminescence monitors in a polluted urban environment, Atmos. Chem. Phys., 7, 2691-2704, doi:10.5194/acp-7-2691-2007, 2007.

Dusanter, S., Vimal, D., Stevens, P. S., Volkamer, R., Molina, L. T., Baker, A., Meinardi, S., Blake, D., Sheehy, P., Merten, A., Zhang, R., Zheng, J., Fortner, E. C., Junkermann, W., Dubey, M., Rahn, T., Eichinger, B., Lewandowski, P., Prueger, J., and Holder, $\mathrm{H}$.: Measurements of $\mathrm{OH}$ and $\mathrm{HO}_{2}$ concentrations during the MCMA-2006 field campaign - Part 2: Model comparison and radical budget, Atmos. Chem. Phys., 9, 6655-6675, doi:10.5194/acp-9-6655-2009, 2009.

Ehhalt, D. H.: Photooxidation of trace gases in the troposphere, Phys. Chem. Chem. Phys., 1, 5401-5408, 1999.

Ehhalt, D. H. and Rohrer, F.: Dependence of the $\mathrm{OH}$ concentration on solar UV, J. Geophys. Res., 105, 3565-3571, 2000.

Elshorbany, Y. F., Kleffmann, J., Hofzumahaus, A., Kurtenbach, R., Wiesen, P., Brauers, T., Bohn, B., Dorn, H.-P., Fuchs, H., Holland, F., Rohrer, F., Tillmann, R., Wegener, R., Wahner, A., Kanaya, Y., Yoshino, A., Nishida, S., Kajii, Y., Martinez, M., Kubistin, D., Harder, H., Lelieveld, J., Elste, T., Plass-DÏmer, C., Stange, G., Berresheim, H., and Schurath, U.: $\mathrm{HO}_{\mathrm{x}}$ budgets during HOxComp: A case study of $\mathrm{HO}_{\mathrm{x}}$ chemistry under $\mathrm{NO}_{\mathrm{x}}$-limited conditions, J. Geophys. Res., 117, D03307, doi:10.1029/2011JD017008, 2012.

Emmerson, K. M., Carslaw, N., and Pilling, M. J.: Urban atmospheric chemistry during the PUMA campaign 2: Radical budgets for $\mathrm{OH}, \mathrm{HO}_{2}$ and $\mathrm{RO}_{2}$, J. Atmos. Chem., 52, 165-183, 2005.

Emmerson, K. M., Carslaw, N., Carslaw, D. C., Lee, J. D., McFiggans, G., Bloss, W. J., Gravestock, T., Heard, D. E., Hopkins, J., Ingham, T., Pilling, M. J., Smith, S. C., Jacob, M., and Monks, P. S.: Free radical modelling studies during the UK TORCH Campaign in Summer 2003, Atmos. Chem. Phys., 7, 167-181, doi:10.5194/acp-7-167-2007, 2007. 
Feister, U. and Grewe, R.: Spectral Albedo Measurements in the Uv and Visible Region over Different Types of Surfaces, Photochem. Photobiol., 62, 736-744, 1995.

Finlayson-Pitts, B. J. and Pitts Jr., J. N.: Chemistry of the upper and lower atmosphere: Theory, experiments and applications, Academic Press, San Diego, 2000.

Fuchs, H., Bohn, B., Hofzumahaus, A., Holland, F., Lu, K. D., Nehr, S., Rohrer, F., and Wahner, A.: Detection of $\mathrm{HO}_{2}$ by laserinduced fluorescence: calibration and interferences from $\mathrm{RO}_{2}$ radicals, Atmos. Meas. Tech., 4, 1209-1225, doi:10.5194/amt4-1209-2011, 2011.

Fuchs, H., Dorn, H.-P., Bachner, M., Bohn, B., Brauers, T., Gomm, S., Hofzumahaus, A., Holland, F., Nehr, S., Rohrer, F., Tillmann, R., and Wahner, A.: Comparison of $\mathrm{OH}$ concentration measurements by DOAS and LIF during SAPHIR chamber experiments at high $\mathrm{OH}$ reactivity and low NO concentration, Atmos. Meas. Tech., 5, 1611-1626, doi:10.5194/amt-5-1611-2012, 2012.

Garland, R. M., Schmid, O., Nowak, A., Achtert, P., Wiedensohler, A., Gunthe, S. S., Takegawa, N., Kita, K., Kondo, Y., Hu, M., Shao, M., Zeng, L. M., Zhu, T., Andreae, M. O., and Pöschl, U.: Aerosol optical properties observed during Campaign of Air Quality Research in Beijing 2006 (CAREBeijing-2006): Characteristic differences between the inflow and outflow of Beijing city air, J. Geophys. Res., 114, D00G04, doi:10.1029/2008JD010780, 2009.

Geiger, H., Barnes, I., Bejan, I., Benter, T., and Spittler, M.: The tropospheric degradation of isoprene: an updated module for the regional atmospheric chemistry mechanism, Atmos. Environ., 37, 1503-1519, 2003.

George, L. A., Hard, T. M., and O'Brien, R. J.: Measurement of free radicals $\mathrm{OH}$ and $\mathrm{HO}_{2}$ in Los Angeles smog, J. Geophys. Res., 104, 11643-11655, 1999.

Gong, J. C., Zhu, T., Hu, M., Zhang, L. W., Cheng, H., Zhang, L., Tong, J., and Zhang, J.: Ambient concentrations of aldehydes in relation to Beijing Olympic air pollution control measures, Atmos. Chem. Phys. Discuss., 10, 19737-19761, doi:10.5194/acpd-10-19737-2010, 2010.

Gunthe, S. S., Rose, D., Su, H., Garland, R. M., Achtert, P., Nowak, A., Wiedensohler, A., Kuwata, M., Takegawa, N., Kondo, Y., Hu, M., Shao, M., Zhu, T., Andreae, M. O., and Pöschl, U.: Cloud condensation nuclei $(\mathrm{CCN})$ from fresh and aged air pollution in the megacity region of Beijing, Atmos. Chem. Phys., 11, 1102311039, doi:10.5194/acp-11-11023-2011, 2011.

Hallquist, M., Wenger, J. C., Baltensperger, U., Rudich, Y., Simpson, D., Claeys, M., Dommen, J., Donahue, N. M., George, C., Goldstein, A. H., Hamilton, J. F., Herrmann, H., Hoffmann, T., Iinuma, Y., Jang, M., Jenkin, M. E., Jimenez, J. L., Kiendler-Scharr, A., Maenhaut, W., McFiggans, G., Mentel, Th. F., Monod, A., Prévôt, A. S. H., Seinfeld, J. H., Surratt, J. D., Szmigielski, R., and Wildt, J.: The formation, properties and impact of secondary organic aerosol: current and emerging issues, Atmos. Chem. Phys., 9, 5155-5236, doi:10.5194/acp-9-51552009, 2009.

Heland, J., Kleffmann, J., Kurtenbach, R., and Wiesen, P.: A new instrument to measure gaseous nitrous acid (HONO) in the atmosphere, Environ. Sci. Techol., 35, 3207-3212, doi:10.1021/es000303t, 2001.

Hofzumahaus, A., Rohrer, F., Lu, K., Bohn, B., Brauers, T., Chang, C. C., Fuchs, H., Holland, F., Kita, K., Kondo, Y., Li, X., Lou,
S., Shao, M., Zeng, L., Wahner, A., and Zhang, Y.: Amplified Trace Gas Removal in the Troposphere, Science, 324, 17021704, 2009.

Holland, F., Hofzumahaus, A., Schäfer, J., Kraus, A., and Pätz, H.W.: Measurements of $\mathrm{OH}$ and $\mathrm{HO}_{2}$ radical concentrations and photolysis frequencies during BERLIOZ, J. Geophys. Res., 108, 8246, doi:10.1029/2001JD001393, 2003.

Jenkin, M. E., Saunders, S. M., Wagner, V., and Pilling, M. J.: Protocol for the development of the Master Chemical Mechanism, MCM v3 (Part B): tropospheric degradation of aromatic volatile organic compounds, Atmos. Chem. Phys., 3, 181-193, doi:10.5194/acp-3-181-2003, 2003.

Jenkin, M. E., Hurley, M. D., and Wallington, T. J.: Investigation of the radical product channel of the $\mathrm{CH}_{3} \mathrm{C}(\mathrm{O}) \mathrm{O}_{2}+\mathrm{HO}_{2}$ reaction in the gas phase, Phys. Chem. Chem. Phys., 9, 3149-3162, 2007.

Jenkin, M. E., Hurley, M. D., and Wallington, T. J.: Investigation of the radical product channel of the $\mathrm{CH}_{3} \mathrm{OCH}_{2} \mathrm{O}_{2}+\mathrm{HO}_{2}$ reaction in the gas phase, J. Phys. Chem. A, 114, 408-416, 2010.

Jimenez, J. L., Canagaratna, M. R., Donahue, N. M., Prevot, A. S. H., Zhang, Q., Kroll, J. H., DeCarlo, P. F., Allan, J. D., Coe, H., Ng, N. L., Aiken, A. C., Docherty, K. S., Ulbrich, I. M., Grieshop, A. P., Robinson, A. L., Duplissy, J., Smith, J. D., Wilson, K. R., Lanz, V. A., Hueglin, C., Sun, Y. L., Tian, J., Laaksonen, A., Raatikainen, T., Rautiainen, J., Vaattovaara, P., Ehn, M., Kulmala, M., Tomlinson, J. M., Collins, D. R., Cubison, M. J., Dunlea, E. J., Huffman, J. A., Onasch, T. B., Alfarra, M. R., Williams, P. I., Bower, K., Kondo, Y., Schneider, J., Drewnick, F., Borrmann, S., Weimer, S., Demerjian, K., Salcedo, D., Cottrell, L., Griffin, R., Takami, A., Miyoshi, T., Hatakeyama, S., Shimono, A., Sun, J. Y., Zhang, Y. M., Dzepina, K., Kimmel, J. R., Sueper, D., Jayne, J. T., Herndon, S. C., Trimborn, A. M., Williams, L. R., Wood, E. C., Middlebrook, A. M., Kolb, C. E., Baltensperger, U., and Worsnop, D. R.: Evolution of Organic Aerosols in the Atmosphere, Science, 326, 1525-1529, 2009.

Kanaya, Y., Cao, R. Q., Akimoto, H., Fukuda, M., Komazaki, Y., Yokouchi, Y., Koike, M., Tanimoto, H., Takegawa, N., and Kondo, Y.: Urban photochemistry in central Tokyo: 1. Observed and modeled $\mathrm{OH}$ and $\mathrm{HO}_{2}$ radical concentrations during the winter and summer of 2004, J. Geophys. Res., 112, D21312, doi:10.1029/2007JD008670, 2007.

Kanaya, Y., Hofzumahaus, A., Dorn, H.-P., Brauers, T., Fuchs, H., Holland, F., Rohrer, F., Bohn, B., Tillmann, R., Wegener, R., Wahner, A., Kajii, Y., Miyamoto, K., Nishida, S., Watanabe, K., Yoshino, A., Kubistin, D., Martinez, M., Rudolf, M., Harder, H., Berresheim, H., Elste, T., Plass-Dülmer, C., Stange, G., Kleffmann, J., Elshorbany, Y., and Schurath, U.: Comparisons of observed and modeled $\mathrm{OH}$ and $\mathrm{HO}_{2}$ concentrations during the ambient measurement period of the $\mathrm{HO}_{\mathrm{x}}$ Comp field campaign, Atmos. Chem. Phys., 12, 2567-2585, doi:10.5194/acp-12-25672012, 2012.

Karl, M., Dorn, H.-P., Holland, F., Koppmann, R., Poppe, D., Rupp, L., Schaub, A., and Wahner, A.: Product study of the reaction of $\mathrm{OH}$ radicals with isoprene in the atmosphere simulation chamber SAPHIR, J. Atmos. Chem., 55, 167-187, 2006.

Kleffmann, J., Lörzer, J., Wiesen, P., Kern, C., Trick, S., Volkamer, R., Rodenas, M., and Wirtz, K.: Intercomparison of the DOAS and LOPAP techniques for the detection of nitrous acid (HONO), Atmos. Environ., 40, 3640-3652, 2006. 
Lawrence, M. G., Jöckel, P., and von Kuhlmann, R.: What does the global mean $\mathrm{OH}$ concentration tell us?, Atmos. Chem. Phys., 1, 37-49, doi:10.5194/acp-1-37-2001, 2001.

Lelieveld, J., Butler, T. M., Crowley, J. N., Dillon, T. J., Fischer, H., Ganzeveld, L., Harder, H., Lawrence, M. G., Martinez, M., Taraborelli, D., and Williams, J.: Atmospheric oxidation capacity sustained by a tropical forest, Nature, 452, 737-740, 2008.

Li, S. P., Matthews, J., and Sinha, A.: Atmospheric hydroxyl radical production from electronically excited $\mathrm{NO}_{2}$ and $\mathrm{H}_{2} \mathrm{O}$, Science, 319, 1657-1660, 2008.

Li, X., Brauers, T., Häseler, R., Bohn, B., Fuchs, H., Hofzumahaus, A., Holland, F., Lou, S., Lu, K. D., Rohrer, F., Hu, M., Zeng, L. M., Zhang, Y. H., Garland, R. M., Su, H., Nowak, A., Wiedensohler, A., Takegawa, N., Shao, M., and Wahner, A.: Exploring the atmospheric chemistry of nitrous acid (HONO) at a rural site in Southern China, Atmos. Chem. Phys., 12, 1497-1513, doi:10.5194/acp-12-1497-2012, 2012.

Li, Y., Shao, M., Lu, S. H., Chang, C. C., and Dasgupta, P. K.: Variations and sources of ambient formaldehyde for the 2008 Beijing Olympic games, Atmos. Environ., 44, 2632-2639, 2010.

Lou, S., Holland, F., Rohrer, F., Lu, K., Bohn, B., Brauers, T., Chang, C., Fuchs, H., Häseler, R., Kita, K., Kondo, Y., Li, X., Shao, M., Zeng, L., Wahner, A., Zhang, Y., Wang, W., and Hofzumahaus, A.: Atmospheric $\mathrm{OH}$ reactivities in the Pearl River Delta - China in summer 2006: measurement and model results, Atmos. Chem. Phys., 10, 11243-11260, doi:10.5194/acp-10-11243-2010, 2010.

Lu, K. D., Zhang, Y. H., Su, H., Brauers, T., Chou, C. C., Hofzumahaus, A., Liu, S. C., Kita, K., Kondo, Y., Shao, M., Wahner, A., Wang, J. L., Wang, X. S., and Zhu, T.: Oxidant $\left(\mathrm{O}_{3}+\mathrm{NO}_{2}\right)$ production processes and formation regimes in Beijing, J. Geophys. Res., 115, D07303, doi:10.1029/2009JD012714, 2010.

Lu, K. D., Rohrer, F., Holland, F., Fuchs, H., Bohn, B., Brauers, T., Chang, C. C., Häseler, R., Hu, M., Kita, K., Kondo, Y., Li, X., Lou, S. R., Nehr, S., Shao, M., Zeng, L. M., Wahner, A., Zhang, Y. H., and Hofzumahaus, A.: Observation and modelling of $\mathrm{OH}$ and $\mathrm{HO}_{2}$ concentrations in the Pearl River Delta 2006: a missing $\mathrm{OH}$ source in a VOC rich atmosphere, Atmos. Chem. Phys., 12, 1541-1569, doi:10.5194/acp-12-1541-2012, 2012.

Mao, J., Ren, X., Chen, S., Brune, W. H., Chen, Z., Martinez, M., Harder, H., Lefer, B., Rappenglück, B., Flynn, J., and Leuchner, M.: Atmospheric oxidation capacity in the summer of Houston 2006: Comparison with summer measurements in other metropolitan studies, Atmos. Environ., 44, 4107-4115, doi:10.1016/j.atmosenv.2009.01.013, 2010.

Mao, J., Ren, X., Zhang, L., Van Duin, D. M., Cohen, R. C., Park, J.-H., Goldstein, A. H., Paulot, F., Beaver, M. R., Crounse, J. D., Wennberg, P. O., DiGangi, J. P., Henry, S. B., Keutsch, F. N., Park, C., Schade, G. W., Wolfe, G. M., Thornton, J. A., and Brune, W. H.: Insights into hydroxyl measurements and atmospheric oxidation in a California forest, Atmos. Chem. Phys., 12, 8009-8020, doi:10.5194/acp-12-8009-2012, 2012.

Martinez, M., Harder, H., Kovacs, T. A., Simpas, J. B., Bassis, J., Lesher, R., Brune, W. H., Frost, G. J., Williams, E. J., Stroud, C. A., Jobson, B. T., Roberts, J. M., Hall, S. R., Shetter, R. E., Wert, B., Fried, A., Alicke, B., Stutz, J., Young, V. L., White, A. B., and Zamora, R. J.: $\mathrm{OH}$ and $\mathrm{HO}_{2}$ concentrations, sources, and loss rates during the Southern Oxidants Study in Nashville, Tennessee, summer 1999, J. Geophys. Res., 108,
4617, doi:10.1029/2003JD003551, 2003.

Matsui, H., Koike, M., Kondo, Y., Takegawa, N., Kita, K., Miyazaki, Y., Hu, M., Chang, S. Y., Blake, D. R., Fast, J. D., Zaveri, R. A., Streets, D. G., Zhang, Q., and Zhu, T.: Spatial and temporal variations of aerosols around Beijing in summer 2006: Model evaluation and source apportionment, J. Geophys. Res., 114, D00G13, doi:10.1029/2008JD010906, 2009.

McKeen, S. A., Mount, G., Eisele, F., Williams, E., Harder, J., Goldan, P., Kuster, W., Liu, S. C., Baumann, K., Tanner, D., Fried, A., Sewell, S., Cantrell, C., and Shetter, R.: Photochemical modeling of hydroxyl and its relationship to other species during the Tropospheric $\mathrm{OH}$ Photochemistry Experiment, J. Geophys. Res., 102, 6467-6493, 1997.

McKenzie, R. L. and Kotkamp, M.: Upwelling UV spectral irradiances and surface albedo measurements at Lauder, New Zealand, Geophys. Res. Lett., 23, 1757-1760, 1996.

Mollner, A. K., Valluvadasan, S., Feng, L., Sprague, M. K., Okumura, M., Milligan, D. B., Bloss, W. J., Sander, S. P., Martien, P. T., Harley, R. A., McCoy, A. B., and Carter, W. P. L.: Rate of Gas Phase Association of Hydroxyl Radical and Nitrogen Dioxide, Science, 330, 646-649, 2010.

Monks, P. S., Granier, C., Fuzzie, S., Stohl, A., Williams, M., Akimoto, H., Ammani, M., Baklanov, A., Baltensperger, U., Bey, I., Blake, N., Blake, R., Carslaw, K., Cooper, O., Dentener, F., Fowler, D., Fragkou, E., Frost, G., Generoso, S., Ginoux, P., Grewe, V., Guenther, A., Hansson, H. C., Henne, S., Hjorth, J., Hofzumahaus, A., Huntrieser, H., Isaksen, I. S. A., Jenkin, M. E., Kaiser, J., Kanakidou, M., Klimont, Z., Kulmala, M., Laj, P., Lawrence, M., Lee, J., Liousse, C., Maione, M., McFiggans, G., Metzger, A., Mieville, A., Moussiopoulos, N., Orlando, J., O’Dowd, C., Palmer, P., Parrish, D., Petzold, A., Platt, U., Pöschl, U., Prévôt, A. S. H., Reeves, C. E., Reimann, S., Rudich, Y., Sellegri, K., Steinbrecher, R., Simpson, D., ten Brink, H., Theloke, J., van der Werf, G. R., Vautard, R., Vestreng, V., Vlachokostas, C., and vonGlasow, R.: Atmospheric Composition Change - Global and Regional Air Quality, Atmos. Environ., 43, 5268-5350, 2009

Parrish, D. D. and Zhu, T.: Clean Air for Megacities, Science, 326 , 674-675, 2009.

Paulot, F., Crounse, J. D., Kjaergaard, H. G., Kroll, J. H., Seinfeld, J. H., and Wennberg, P. O.: Isoprene photooxidation: new insights into the production of acids and organic nitrates, Atmos. Chem. Phys., 9, 1479-1501, doi:10.5194/acp-9-1479-2009, 2009.

Peeters, J. and Müller, J.-F.: $\mathrm{HO}_{\mathrm{x}}$ radical regeneration in isoprene oxidation via peroxy radical isomerisations. II: experimental evidence and global impact, Phys. Chem. Chem. Phys., 12, 1422714235, doi:10.1039/c0cp00811g, 2010.

Peeters, J., Nguyen, T. L., and Vereecken, L.: $\mathrm{HO}_{\mathrm{x}}$ radical regeneration in the oxidation of isoprene, Phys. Chem. Chem. Phys., 11, 5935-5939, 2009

Poppe, D., Wallasch, M., and Zimmermann, J.: The Dependence of the Concentration of $\mathrm{OH}$ on its Precursors under Moderately Polluted Conditions: A Model Study, J. Atmos. Chem., 16, 6178, 1993

Pöschl, U., von Kuhlmann, R., Poisson, N., and Crutzen, P. J.: Development and intercomparison of condensed isoprene oxidation mechanisms for global atmospheric modeling, J. Atmos. Chem., 37, 29-52, 2000. 
Pugh, T. A. M., MacKenzie, A. R., Hewitt, C. N., Langford, B., Edwards, P. M., Furneaux, K. L., Heard, D. E., Hopkins, J. R., Jones, C. E., Karunaharan, A., Lee, J., Mills, G., Misztal, P., Moller, S., Monks, P. S., and Whalley, L. K.: Simulating atmospheric composition over a South-East Asian tropical rainforest: performance of a chemistry box model, Atmos. Chem. Phys., 10, 279-298, doi:10.5194/acp-10-279-2010, 2010.

Ren, X., Harder, H., Martinez, M., Lesher, R. L., Oliger, A., Simpas, J. B., Brune, W. H., Schwab, J. J., Demerjian, K. L., He, Y., Zhou, X., and Gao, $\mathrm{H} .: \mathrm{OH}$ and $\mathrm{HO}_{2}$ Chemistry in the urban atmosphere of New York City, Atmos. Environ., 37, 3639-3651, 2003.

Ren, X., Olson, J. R., Crawford, J. H., Brune, W. H., Mao, J., Long, R. B., Chen, G., Avery, M. A., Sachse, G. W., Barrick, J. D., Diskin, G. S., Huey, L. G., Fried, A., Cohen, R. C., Heikes, B., Wennberg, P., Singh, H. B., Richard, D. R. B., and Shetter, E.: $\mathrm{HO}_{\mathrm{x}}$ Chemistry during INTEX-A 2004: Observation, Model Calculations and comparison with previous studies, J. Geophys. Res., 113, D05310, doi:10.1029/2007JD009166, 2008.

Richter, A., Burrows, J. P., Nüß, H., Granier, C., and Niemeier, U.: Increase of tropospheric nitrogen dioxide over China observed from space, Nature, 437, 129-132, 2005.

Rohrer, F. and Berresheim, H.: Strong correlation between levels of tropospheric hydroxyl radicals and solar ultraviolet radiation, Nature, 442, 184-187, 2006.

Saunders, S. M., Jenkin, M. E., Derwent, R. G., and Pilling, M. J.: Protocol for the development of the Master Chemical Mechanism, MCM v3 (Part A): tropospheric degradation of nonaromatic volatile organic compounds, Atmos. Chem. Phys., 3, 161-180, doi:10.5194/acp-3-161-2003, 2003.

Shao, M., Tan, X., Zhang, Y., and Li, W.: City clusters in China: air and surface water pollution, Front. Ecol. Environ., 4, 353-361, 2006.

Sheehy, P. M., Volkamer, R., Molina, L. T., and Molina, M. J.: Oxidative capacity of the Mexico City atmosphere - Part 2: $\mathrm{A} \mathrm{RO}_{\mathrm{x}}$ radical cycling perspective, Atmos. Chem. Phys., 10, 6993-7008, doi:10.5194/acp-10-6993-2010, 2010.

Shirley, T. R., Brune, W. H., Ren, X., Mao, J., Lesher, R., Cardenas, B., Volkamer, R., Molina, L. T., Molina, M. J., Lamb, B., Velasco, E., Jobson, T., and Alexander, M.: Atmospheric oxidation in the Mexico City Metropolitan Area (MCMA) during April 2003, Atmos. Chem. Phys., 6, 2753-2765, doi:10.5194/acp-62753-2006, 2006.

Stockwell, W. R., Kirchner, F., Kuhn, M., and Seefeld, S.: A new mechanism for regional atmospheric chemistry modeling, J. Geophys. Res., 102, 25847-25879, 1997.

Streets, D. G., Fu, J. S., Jang, C. J., Hao, J. M., He, K. B., Tang, X. Y., Zhang, Y. H., Wang, Z. F., Li, Z. P., Zhang, Q., Wang, L. T., Wang, B. Y., and Yu, C.: Air quality during the 2008 Beijing Olympic Games, Atmos. Environ., 41, 480-492, 2007.

Su, H., Cheng, Y. F., Shao, M., Gao, D. F., Yu, Z. Y., Zeng, L. M., Slanina, J., Zhang, Y. H., and Wiedensohler, A.: Nitrous acid (HONO) and its daytime sources at a rural site during the 2004 PRIDE-PRD experiment in China, J. Geophys. Res., 113, D14312, doi:10.1029/2007JD009060, 2008.
Takegawa, N., Miyakawa, T., Kuwata, M., Kondo, Y., Zhao, Y., Han, S., Kita, K., Miyazaki, Y., Deng, Z., Xiao, R., Hu, M., van Pinxteren, D., Herrmann, H., Hofzumahaus, A., Holland, F., Wahner, A., Blake, D. R., Sugimoto, N., and Zhu, T.: Variability of submicron aerosol observed at a rural site in Beijing in the summer of 2006, J. Geophys. Res., 114, D00G05, doi:10.1029/2008JD010857, 2009.

Tan, D., Faloona, I., Simpas, J. B., Brune, W., and Shepson, P. B.: $\mathrm{HO}_{\mathrm{x}}$ budgets in a deciduous forest: Results from the PROPHET summer 1998 campaign, J. Geophys. Res., 106, 24407-24427, 2001.

Taraborrelli, D., Lawrence, M. G., Butler, T. M., Sander, R., and Lelieveld, J.: Mainz Isoprene Mechanism 2 (MIM2): an isoprene oxidation mechanism for regional and global atmospheric modelling, Atmos. Chem. Phys., 9, 2751-2777, doi:10.5194/acp-92751-2009, 2009.

Toenges-Schuller, N., Stein, O., Rohrer, F., Wahner, A., Richter, A., Burrows, J. P., Beirle, S., Wagner, T., Platt, U., and Elvidge, C. D.: Global distribution pattern of anthropogenic nitrogen oxide emissions: Correlation analysis of satellite measurements and model calculations, J. Geophys. Res., 111, 312, doi:10.1029/2005JD006068, 2006.

Volkamer, R., Sheehy, P., Molina, L. T., and Molina, M. J.: Oxidative capacity of the Mexico City atmosphere - Part 1: A radical source perspective, Atmos. Chem. Phys., 10, 6969-6991, doi:10.5194/acp-10-6969-2010, 2010.

Wang, T., Ding, A. J., Gao, J., and Wu, W. S.: Strong ozone production in urban plumes from Beijing, China, Geophys. Res. Lett., 33, L21806, doi:10.1029/2006GL027689, 2006.

Weinstock, B., Niki, H., and Chang, T. Y.: Chemical Factors Affecting the Hydroxyl Radical Concentration in the Troposphere, Adv. Environ. Sci. Technol., 10, 221-258, 1980.

Whalley, L. K., Edwards, P. M., Furneaux, K. L., Goddard, A., Ingham, T., Evans, M. J., Stone, D., Hopkins, J. R., Jones, C. E., Karunaharan, A., Lee, J. D., Lewis, A. C., Monks, P. S., Moller, S. J., and Heard, D. E.: Quantifying the magnitude of a missing hydroxyl radical source in a tropical rainforest, Atmos. Chem. Phys., 11, 7223-7233, doi:10.5194/acp-11-7223-2011, 2011.

Wiedensohler, A., Cheng, Y. F., Nowak, A., Wehner, B., Achtert, P., Berghof, M., Birmili, W., Wu, Z. J., Hu, M., Zhu, T., Takegawa, N., Kita, K., Kondo, Y., Lou, S. R., Hofzumahaus, A., Holland, F., Wahner, A., Gunthe, S. S., Rose, D., Su, H., and Pöschl, U.: Rapid aerosol particle growth and increase of cloud condensation nucleus activity by secondary aerosol formation and condensation: A case study for regional air pollution in northeastern China, J. Geophys. Res., 114, D00G08, doi:10.1029/2008JD010884, 2009.

Wolfe, G. M., Crounse, J. D., Parrish, J., J., S., Yoon, T. P., Wennberg, P. O., and Keutsch, F. N.: Photolysis and OH reactivity of a Proxy for Isoprene-derived Hydroperoxyenals, Phys. Chem. Chem. Phys., 14, 7276-7286, doi:10.1039/c2cp40388a, 2012.

Xie, X., Shao, M., Liu, Y., Lu, S. H., Chang, C. C., and Chen, Z. M.: Estimate of initial isoprene contribution to ozone formation potential in Beijing, China, Atmos. Environ., 42, 6000-6010, 2008. 